UNITED STATES DEPARTMENT OF THE INTERIOR

Harold L. Ickes, Secretary

GEOLOGICAL SURVEY

W. C. Mendenhall, Director

\title{
Bulletin 900
}

\section{SUBSURFACE GEOLOGY \\ AND OIL AND GAS RESOURCES OF OSAGE COUNTY, OKLAHOMA}

BY

N. W. BASS AND OTHERS
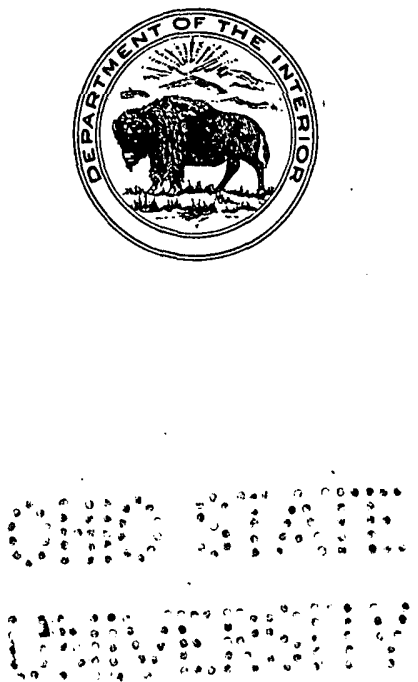

UNITED STATES

GOVERNMENT PRINTING OFFICE

WASHINGTON : 1942 
QE75

By

no. 900

cruptz

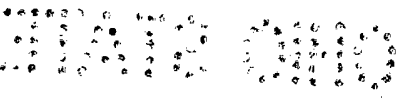

? 


\section{CONTENTS}

[The letters in parentheses preceding the titles are those used to designate the papers for advanice publication ]

Page

(A) Part 1, Townships 22 and 23 north, ranges 10 and 11 east, Osage County, Okla., by N. W. Bass, L. E.'Kennedy, W. R. Dillard, Otto Leatherock, and J. H. Hengst.

(B) Part 2, Townships 22 and 23 north, ranges 8 and 9 east, by C. T. Kirk, H. D. Jenkins, Otto Leatherock, W. R. Dillard, L. E. Kennedy, and N. W. Bass

(C) Part 3, Townships 24 and 25 north, ranges 8 and 9 east, by N. W. Bass, L. E. Kennedy, J. N. Conley, and J. H. Hengst

(D) Part 4, Townships 24 and 25 north, ranges 10 and 11 east, by $\mathrm{L}$. $\mathrm{E}$. Kennedy, J. D. McClure, H. D. Jenkins, and N. W. Bass_

(E) Part 5, Townships 26 and 27 north, ranges 10 and 11 east, by L. E. Kennedy, W. E. Shamblin, Otto Leatherock, and N. W. Bass

(F) Part 6, Township 28 north, ranges 10 and 11 east, and township 29 north, ranges 9 to 11 east_

(G) Part 7, Townships 20 and 21 north, ranges 11 and 12 east, by W. $\mathbf{R}$. Dillard, N. W. Bass, and C. T. Kirk

(H) Part 8, Parts of township 20 north, ranges 9 and 10 east, and township 21 north, ranges 8 and 9 east, and all of township 21 north, range 10 east, by C. T. Kirk, W. R. Dillard, Otto Leatherock, and H. D. Jenkins

(I) Part 9, Townships 23 and 24 north, range 7 east, by N. W. Bass, W. R. Dillard, L. E. Kennedy, and H. B. Goodrich

(J) Part 10, Burbank and South Burbank oil fields, townships 26 and 27 north, range 5 east, and townships 25 to 27 north, range 6 east, Osage and Kay Counties, Okla., by N. W. Bass, H. B. Goodrich, and W. R. Dillard

(K) Part 11, Summary of subsurface geology with special reference to oil and gas, by N. W. Bass

\section{ILLUSTRATIONS}

Prite 1. Map of Tps. 22 and 23 N., Rs. 10 and 11 E., Osage County, Okla _._._. In pocket

2. Map of Tps. 22 and 23 N., Rs. 8 and $9 \mathrm{E}$

3. Map of Tps. 24 and 25 N., Rs. 8 and $9 \mathrm{E}_{\ldots}$

4. Map of Tps. 24 and $25 \mathrm{~N}$., Rs. 10 and $11 \mathrm{E}$

5. Map of Tps. 26 and $27 \mathrm{~N}$., Rs. 10 and $11 \mathrm{E}_{\ldots}$

6. Map of T. 28 N., Rs. 10 and 11 E., and T. 29 N., Rs. 9 to $11 \mathrm{E}_{-}$

7. Map of Tps. 20 and 21 N., Rs. 11 and 12 E_________- In pocket

8. Map of parts of T. 20 N., Rs. 9 and 10 E., and T. 21 N., Rs.

8 and 9 E., and all of T. 21 N., R. 10 E________._._._. In pocket 
Plate 9. Map of Tps. 23 and 24 N., R. 7 E-

Page

10. Map of the Burbank and South Burbank oil fields, Tps. 26 and 27 N., R. 5 E., and Tps. 25 to 27 N., R. 6 E., Osage and Kay Counties, Okla

In pocket,

in

11. Map of the Burbank and South Burbank oil fields showing thickness of the Burbank sand as recorded in driller's'

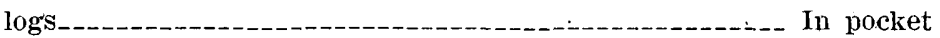

12. Map of the Burbank and South Burbank oil fields showing

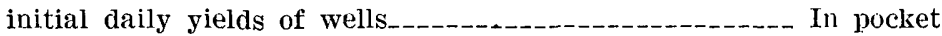

13. Fred Lookout, Principal Chief, Osage 'Tribe_____._. 346

14. Geologic section northwest-southeast across Osage County - In pocket

15. Map of Osage County showing oil and gas fields___-____- In pocket

16. Map showing oil and gas pools in the Ordovician beds, mainly in the Siliceous lime-_____._-_._- In pocket

17. Map showing oil and gas pools in the Burgess sand-Mis-

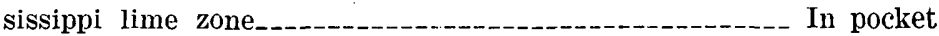

18. Map showing oil and gas pools in the Bartlesville sand and oil pools in the Burbank (Red Fork) sand_..._._.......- In pocket

19. Map showing oil and gas pools in the Wayside sand and the Jones and Cleveland sand zone______________._- In pocket

20. Geologic section across eastern Osage County showing stratigraphic relationship of the Wayside sand and the Jones and Cleveland sand zone_....._._._. In pocket

FIgure 1. Index map of Oklahoma showing the location of Osage County 2

2. Sketch at the close of the Shidler stage showing the sand body - of the Burbank field and a hypothetical sand body

3. Sketch at the close of the Stanley stringer-South Burbank stage showing the sand bodies of the Burbank and South Burbank fields and parts of hypothetical sand bodies

4. Index map of Osage County showing areas described in parts 1 to 10 of this report (Bull. $900-\mathrm{A}$ to $900-\mathrm{J}$ )

5. Total oil produced from Osage County by fiscal years_.........-

6. Annual receipts of the Osage Tribe from oil and gás royalties, bonuses, and rentals 
UNITED STATES DEPARTMENT OF THE INTERIOR

Harold L. Ickes, Secretary

GEOLOGICAL SURVEY

W. C. Mendenhall, Director

\title{
Bulletin 900-A
}

SUBSURFACE GEOLOGY

AND OIL AND GAS RESOURCES OF

OSAGE COUNTY, OKLAHOMA

\author{
Part 1. Townships 22 and 23 North \\ Ranges 10 and 11 East
}

BY

N. W. BASS, L. E. KENNEDY, W. R. DILLARD, OTTO LEATHEROCK, and J. H. HENGST

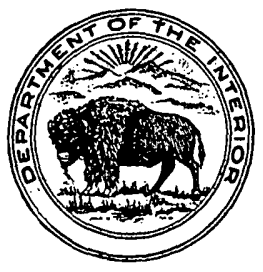

UNITED STATES

GOVERNMENT PRINTING OFFICE

WASHINGTON : 1938

For sale by the Superintendent of Documents, Washington, D. C. - - - - Price 30 cents 


\section{FOREWORD}

This report on the subsurface geology of Osage County, Okla., describes the structural features, the character of the oil- and gas-producing beds, and the localities where additional oil and gas may be found. It embodies a part of the results of a subsurface geologic investigation of the Osage Indian Reservation, which coincides in area with Osage County. The investigation was conducted by a field party of the Geological Survey of the United States Department of the Interior in 1934 to 1937 and involved the study of the records of about 17,000 wells that have been drilled in Osage County. Funds for the investigation were allotted to the Geological Survey by the Public Works Administration. The primary purpose of the examination was to obtain geologic data for use in the administration of the Indian lands. The results of the inquiry have shown that many localities in Osage County outside the present producing oil fields are worthy of prospecting for oil and gas and that additional oil and gas can be found also by exploring deeply buried beds in old producing fields.

All townships in Osage County that contain many wells are described; the information furnished by such townships is ample for drawing detailed subsurface structure-contour maps. The descriptions of several contiguous townships are combined in separate reports, which are issued as parts of a single bulletin. No edition of the consolidated volume will be published, but the several parts can be bound together if desired.

The subsurface investigation of Osage County was carried on mainly by L. E. Kennedy, W. R. Dillard, H. B. Goodrich, Charles T. Kirk, J. D. McClure, Otto Leatherock, Constance Leatherock, W. E. Shamblin, J. N. Conley, H. D. Jenkins, J. H. Hengst, G. D. Gibson, and N. W. Bass, geologists. The work of each geologist contributed more or less to the results of the investigation in each township. However, the investigations of the individual townships in Osage County were made mainly by various individuals of the group, and their names appear in the township descriptions. In addition to those whose names appear above, valuable assistance in the compilation of information was given by Lucile Linton, S. B. Thomas, R. C. Beckstrom, B. A. Lilienborg, J. G. Dwen, K. H. Johnson, J. G. Beaulieu, C. R. Viers, E. L. Hitt, Grace Clark, R. A. Payne, and J. C. Rollins.

Oil companies and individuals who contributed information are too numerous to acknowledge all by name. Special mention is made, however, of LaughlinSimmons \& Co. and the Indian Territory Illuminating Oil Co. for supplying most of the well elevations used in Osage County; of the Continental Oil Co., Tidal Oil Co., Sinclair Prairie Oil Co., Indian Territory Illuminating Oil Co., Phillips Petroleum Co., W. C. McBride, Inc., The Carter Oil Co., and others for supplying well logs, maps, cuttings, and cores of the producing sands in Osage County.

H. D. Miser, geologist in charge of the section of geology of fuels, supervised the work upon which this report is based. Appreciative acknowledgment is here made of many suggestions made by him during the progress of the investigation and during the preparation of the manuscript. Grateful acknowledgment is due the officers of the Osage Indian Agency at Pawhuska and the late John M. Alden, Foster Morrell, and others in the Tulsa office of the Geological Survey for cooperation and assistance; also Hale B. Soyster and H. I. Smith, of the Geological Survey, for sponsorship and interest in the investigation.

N. W. BAss. 


\section{CONTENTS}

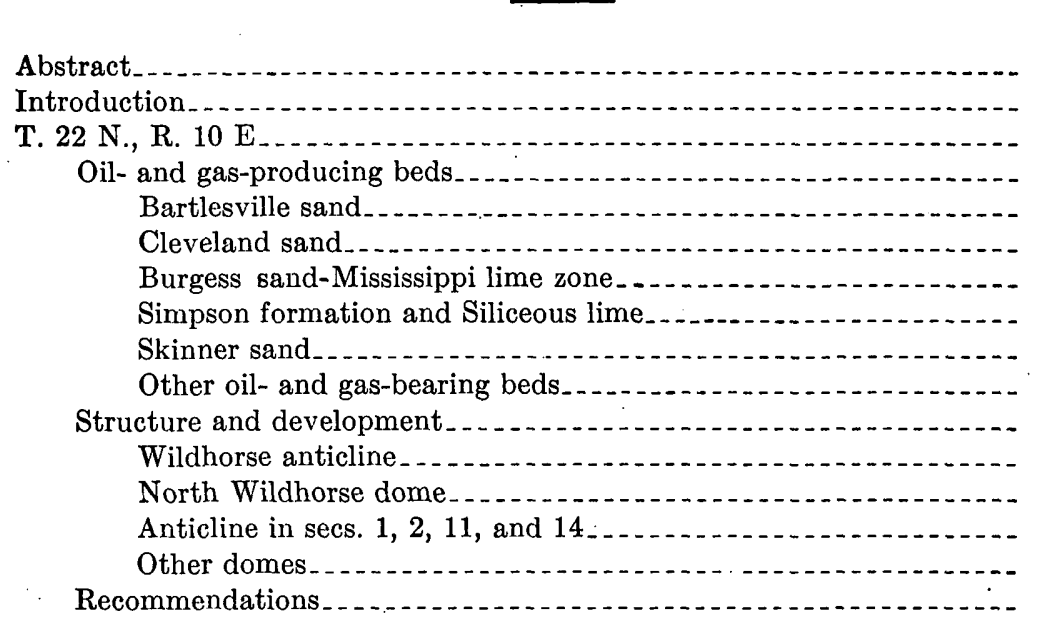

Oil- and gas-producing beds

Bartlesville sand.

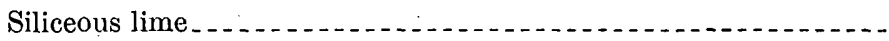

Other oil- and gas-bearing beds...... 16

Oil yields..........

Structure and development. 18

Recommendations

T. 22 N., R. 11 E.

Oil- and gas-producing beds......... 22

Bartlesville sand.......... 22

Red Fork sand.

Burgess sand-Mississippi lime zone...... 23

Big lime......... 24

Ordovician rocks

Taneha sand

Oswego lime $\ldots$.

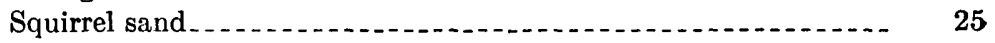

Structure and development._.

South Brown anticline.

South Fox dome (secs. 5 and 6) 29

Cedar Bluff dome....... 30

Secs. 22 and $23 . \ldots 1$

Sec. $36 \ldots \ldots \ldots$

Lake View dome.

Secs. 31 and $32 \ldots$

Anticline in northeastern part of township..... 33

Recommendations 
T. $23 \mathrm{~N}, \mathrm{R}, 11 \mathrm{E}-3$

Oil- and gas-producing beds.

Bartlesville sand.............. 35

Burgess sand-Mississippi lime zone

Cleveland sand

Big lime........ 37

Ordovician rocks

Red Fork sand............ 38

Oswego lime and Squirrel sand.......................... 38

Structure and development.... 38

Brown anticline .................. 40

Fox dome

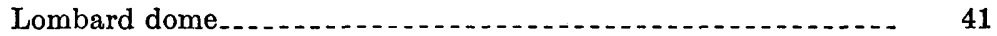

Anticline in sec. 8.......... 42

Hardy dome. . .

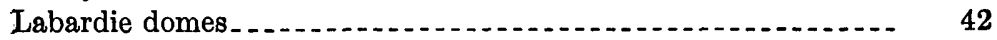

Other domes and anticlines........................... 43

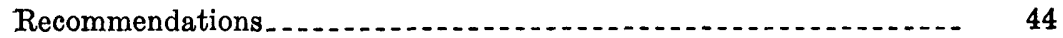

\section{ILLUSTRATIONS}

Prate 1. Map of Tps. 22 and 23 N., Rs. 10 and 11 E., Osage County,

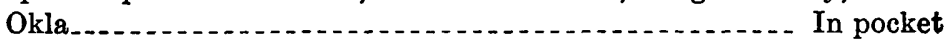

Figdre 1. Index map of Oklahoma showing the location of Osage County- 2 


\title{
SUBSURFACE GEOLOGY AND OIL AND GAS RESOURCES OF OSAGE COUNTY, OKLAHOMA
}

\author{
Part 1. Townships 22 and 23 North, Ranges 10 and 11 East
}

\author{
By N. W. Bass, L. E. Kennedy, W. R. Dillard, Otto Leatherock, \\ and J. H. Hengst
}

\begin{abstract}
The four townships-Tps. 22 and 23 N., Rs. 10 and 11 E.-whose subsurface geology and oil and gas resources are described in this report, lie in southeastern Osage County, Okla., 12 to 25 miles northwest of Tulsa. They are in the midst of a region that has many oil and gas fields, and these four townships contain more than 1,800 wells. Oil or gas is produced from 11 beds, all of which lie at depths of less than 2,600 feet in most parts of the four townships. Nine of the oil- and gas-bearing beds are in the Pennsylvanian series, one is in the Mississippian series, and one is in the Ordovician system. The producing beds in the Mississippian and Ordovician rocks, however, range through relatively thick sequences of beds. The Bartlesville sand, which is in the lower part of the Pennsylvanian series, has produced oil and gas in more wells than all the other beds combined.

The four townships are in a broad region that includes most of northeastern Oklahoma, in which the rocks dip westward at an average rate of about 40 feet to the mile. The regional westerly dip is not uniform, however, but is interrupted by domes, anticlines, synclines, and basins, most of which have a structural closure of less than 100 feet on the Oswego lime. The top of the Oswego lime (Fort Scott limestone) is the subsurface datum used in drawing the structure contours shown on plate 1.

Oil in the Ordovician beds and to a less extent in several of the other beds appears to be concentrated in the domes and anticlines. The occurrence of oil and gas in the Bartlesville sand and probably in some of the other sands is controlled by the distribution of the reservoir beds rather than by the structural attitude of the beds.

The investigation has shown that in Tps. 22 and 23 N., Rs. 10 and 11 E., there are several localities outside the oil fields where prospecting may reveal new oil and gas deposits. Deep drilling in some of the producing fields should result in discovering additional oil and gas in beds that lie below tho present producing beds. Recent experience in Osage County and elsewhere in the adjoining portion of the Mid-Continent region shows that additional oil can be had by treating the limestone reservoir beds with acid. Much oil will also eventually be produced by repressuring and water flooding in fields that derive their oil from the Bartlesville, Cleveland, and other sandstone reservoir beds.
\end{abstract}




\section{INTRODUCTION}

The subsurface geologic features, the oil- and gas-producing beds, and the areas and beds that are favorable for additional prospecting for oil and gas in Tps. 22 and 23 N., Rs. 10 and 11 E., Osage County, Okla., are described in this report. The structural attitude of the buried rocks, the oil and gas wells, abandoned wells and dry holes, and the ownership of leases are shown on the accompanying map (pl. 1). The oil- or gas-producing bed in each well is shown on the map by color tints over the black well symbols. Wells that produced oil or gas from shallow beds and were drilled deeper to test older rocks are indicated by special symbols.

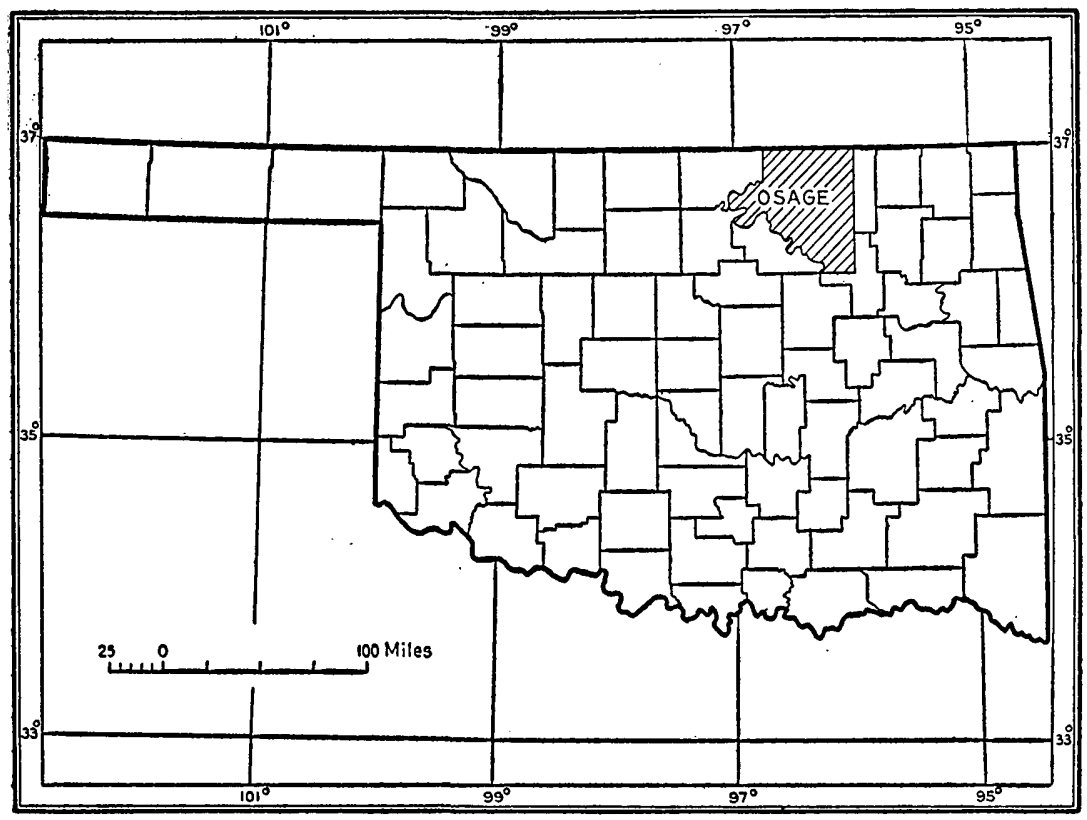

Figurp 1.-Index map of Oklahoma showing the location of Osage County.

Eleven beds produce oil or gas in the four townships here described. They are indicated on the generalized columnar section on plate 1 by means of colored solid circles. The colors used on the columnar section correspond to the color overprints on the wells shown on the map. The oil- and gas-producing beds in each of the four townships are shown also in the table on page 3.

The location of Osage County is shown on the index map (fig. 1). The four townships described in this report are in the southeastern part of the county; their exact location is shown on the key map on plate 1. 
Oil- or gas-producing beds in Tps. 22 and $2 S \mathrm{~N}$., Rs. 10 and $11 \mathrm{E}$., Osage County, Okla.

\begin{tabular}{|c|c|c|c|}
\hline T. 22 N., R. 10 E. & T. 23 N., R. 10 E. & T. 22 N., R. 11 E. & T. 23 N., R. 11 E. \\
\hline $\begin{array}{l}\text { Layton sand. } \\
\text { Cleveland sand. } \\
\text { Big lime. } \\
\text { Oswego lime. } \\
\text { skinner sand. } \\
\text { Bartlesville sand. } \\
\text { Burgess sand-Mississippi } \\
\text { lime zone. } \\
\text { Simpson formation or } \\
\text { Siliceous lime. }\end{array}$ & $\begin{array}{l}\text { Squirrel sand. } \\
\text { Skinner sand. } \\
\text { Bartlesville sand. } \\
\text { Burgess sand-Mississippi } \\
\text { lime zone. } \\
\text { Simpson formation or } \\
\text { Siliceous lime. }\end{array}$ & $\begin{array}{l}\text { Big lime. } \\
\text { Oswego lime. } \\
\text { Squirrel sand. } \\
\text { Red Fork sand. } \\
\text { Bartlesville sand. } \\
\text { Taneha sand. } \\
\text { Burgess sand-Mississippi } \\
\text { lime zone. } \\
\text { Simpson formation or } \\
\text { Siliceous lime. }\end{array}$ & $\begin{array}{l}\text { Cleveland sand. } \\
\text { Big lime. } \\
\text { Oswego lime. } \\
\text { Squirrel sand. } \\
\text { Red Fork sand. } \\
\text { Bartlesville sand. } \\
\text { Burgess sand-Mississippi } \\
\text { lime zone. } \\
\text { Simpson formation or } \\
\text { siliceous lime. }\end{array}$ \\
\hline
\end{tabular}

The distribution of the surface beds, which include the Nellie Bly, Dewey limestone, Ochelata, and Nelagoney formations of the Pennsylvanian series, is shown on the State geologic map. ${ }^{1}$ The character and structural attitude of the exposed beds in Tps. 22 and $23 \mathrm{~N}$., R. 11 E., were set forth many years ago by Emery and Ross ${ }^{2}$ and those in Tps. 22 and 23 N., R. 10 E., were mapped by Wood ${ }^{3}$ between 1912 and 1917. The results of Wood's work were not published. The structure-contour maps of the exposed beds prepared by Emery, Ross, and Wood were used extensively in the drawing of the structure contours on plate 1 . In areas that contain few wells the structural interpretation shown on plate 1 is controlled largely by these structure-contour maps of the surface beds, but in areas that contain many wells subsurface data are ample for drawing the structure contours of the unexposed rocks.

\section{T. 22 N., R. 10 E.}

T. 22 N., R. 10 E., is in southeastern Osage County, about 15 miles northwest of Tulsa, which is adjacent to the southeast corner of the county. A total area of a little more than 5 square miles is oilbearing, and a few areas in the oil fields yield gas. A total of 700 wells, including oil and gas producers and dry holes, have been drilled in the township.

The years 1919 and 1920 witnessed the greatest drilling activity in the township. During these two years the Wildhorse oil field, in the southernmost part of the township; the North Wildhorse field, in secs. 17 to 20 ; and the small field in the central and northeastern parts of sec. 23 were all largely developed. Most of the wells in the oil field that trends northeastward through parts of secs. $26,25,24$,

\footnotetext{
1 Miser, H. D., Geologic map of Oklahoma, U. S. Geol. Survey, 1926.

2 Emery, W. B., and Ross, C. S., in White, David, and others, Structure and oil and gas resources of the Osage Reservation, Oklahoma : U. S. Geol. Survey Bull. 686, pp. 1-9, 179-191, and pls. 3 and $30,1922$.

3 Wood, R. H., Unpublished map of parts of the Hominy quadrangle, in U. S. Geological Survey files.
} 
and 13, and the wells in the NW1/4 sec. 36 were drilled in 1912 and 1913. Most of the oil producers in the $\mathrm{W}^{1} 1 / 2$ sec. 26 and the NE1/4 sec. 27 were drilled in 1913 and 1914. Several wells in the small field surrounding the corner common to secs. $1,2,11$, and 12 were drilled in 1916, and most of the other wells in this field were drilled in 1923 and 1924.

Depths to the oil-bearing beds differ considerably in the various parts of the township. The gas-bearing Bartlesville sand lies at a depth of about 1,700 feet and the oil-bearing Siliceous lime at about 2,200 feet in the small pool that occupies parts of secs. 1, 2, 11, and 12. The depth to the Bartlesville sand in secs. 13 and 23 to 26 is about 1,700 feet. The Skinner sand lies at a depth of 1,700 feet in the W1/2 sec. 26 and the E1/2 sec. 27. The Cleveland sand lies at a depth of about 1,200 feet in the NW1/4 sec. 36 and the NE1/4 sec. 35, and at about 1,150 feet in much of the large Wildhorse oil field, in the southcentral part of the township. The Bartlesville sand in the Wildhorse field occurs at a depth of about 1,800 to 1,850 feet, the Burgess sandMississippi lime zone at about 2,000 feet, and the Siliceous lime at about 2,300 feet. In the North Wildhorse oil field, the Bartlesville sand lies at a depth of about 1,800 feet, the Burgess sand-Mississippi lime zone at a little below 1,900 feet, and the Siliceous lime at about 2,200 feet.

An initial yield of considerably less than 50 barrels of oil a day was made by most of the wells producing from the Bartlesville sand. Some of the Bartlesville sand producers, however, produced initially more than 100 barrels of oil a day, and a few, particularly those in the North Wildhorse field, yielded several hundred barrels a day. The initial yield of most wells producing from the Skinner sand and of those producing from the Cleveland sand was less than 50 barrels a day. The wells in the Cleveland sand commonly had smaller initial yields than those in the Bartlesville sand. The initial yields of wells producing from the Burgess sand-Mississippi lime zone had a wide range but were commonly small. The initial yields of the wells in the Siliceous lime differed widely; the maximum initial daily yield from the Siliceous lime was 1,000 barrels, and several wells yielded initially several hundred barrels of oil a day.

The gas wells in T. 22 N., R. 10 E., had initial yields that ranged between half a million and 18 million cubic feet of gas a day.

The subsurface geologic investigation of T. 22 N., R. 10 E., whose results are shown on plate 1 was made by W. R. Dillard, Jess H. Hengst, L. E. Kennedy, and N. W. Bass.

\section{OIL- AND GAS-PRODUCING BEDS}

Oil or gas has been produced from eight beds, ranging from the Siliceous lime, at a depth of about 2,200 to 2,300 feet, to the Layton 
sand, at a depth of 850 feet. The beds from the lowest upward are the Siliceous lime, Burgess sand-Mississippi lime zone, Bartlesville sand, Skinner sand, Oswego lime, Big lime, Cleveland sand, and Layton sand. The Bartlesville sand yields oil or gas in many more wells than the other beds, and the Cleveland sand ranks second. The Siliceous lime is an important reservoir bed in a few areas. Only a very few wells found oil or gas in the Oswego lime, Big lime, or Layton sand. The chief oil- or gas-bearing beds are described briefly below in the order of their productiveness.

Bartlesville sand.-The Bartlesville sand, which occurs at depths ranging from about 1,700 to 1,900 feet, has produced oil in a northeastward-trending belt about a mile wide in the eastern part of the township, in an eastward-trending belt about $1 \frac{1}{2}$ miles wide in the southernmost part of the township, and in a relatively small area in the west-central part. Locally this sand has yielded only gas in these oil-producing fields and in a small field in the northeastern part of the township. In most of the oil fields gas occurs in the upper part of the sand and oil in the lower part. The Bartlesville sand, whose base is about 50 feet above the base of the Cherokee shale, occurs as lenses that range from less than 10 to 150 feet in thickness. The lenses of sand in the various parts of the township appear not to be equivalent. For instance, the Bartlesville sand in the Wildhorse oil field (secs. 27-29 and 32-35) appears to occur at the stratigraphic position of the oil-producing sand in the North Wildhorse field (secs. 17-20), but the elongated belt of oil-producing sand in secs. 13 and 23 to 26 is 50 to 75 feet higher. In fact, the oil-bearing sand in secs. 13 and 23 to 26 is so high stratigraphically that it appears to occupy in part the position of the Red Fork sand of south-central Osage County. It is questionable whether the sand should properly be designated the Bartlesville or the Red Fork.

The Bartlesville sand in the North Wildhorse and Wildhorse fields is commonly 75 feet thick and free from partings of shale, according to the well logs. The sand in most places in secs. 13 and 23 to 26 is only 20 to 30 feet thick, however, and is separated by partings of shale into several beds. The logs of a few wells record all the beds at the horizon of the Bartlesville sand as shale, and a regional investigation suggests that sandy shale and shale beds really occupy the position of the Bartlesville sand in many dry holes outside the oil fields although sand is recorded in the well logs by the drillers.

More than half of the 350 wells in this township that have produced oil from the Bartlesville sand yielded initially less than 50 barrels of oil a day each. About one-fifth of the wells each yielded initially 50 to 100 barrels a day; one-tenth yielded 100 to 200 barrels; another one-tenth yielded 200 to 500 barrels; and fewer than 10 wells 41865-38-2 
yielded initially more than 500 barrels of oil a day. One well-No. 1 in the northwest corner of sec. 20 (see pl. 1), known as the Bearcatwas reported to have yielded initially at the rate of 7,000 barrels of oil a day. ${ }^{4}$ The lease on which it is situated is locally called the Bearcat lease because of the remarkable performance of this well.

Cleveland sand.-A sequence of beds composed largely of sandstone with a total thickness of about 100 feet occurs in the lower part of the Coffeyville formation and yields considerable amounts of oil in about 170 wells in the Wildhorse oil field (secs. 27-29 and 32-35). In southern Osage County two sandstone beds separated by shale occur in this part of the Coffeyville formation in some places; the upper sandstone is known as the Jones sand and the lower as the Cleveland sand.

The two sands are not distinguished in T. 22 N., R. 10 E., but the thick bed of sandstone present here is designated in this report the Cleveland sand, although it is uncertain whether it also represents the Jones sand. The sand is recorded as being thin in many wells and totally absent in others in the western, central, and northern parts of the township but is recorded in the logs of nearly all wells in the southern half of the township. The sand commonly yields a show of gas where it is present outside the Wildhorse oil field. Gas occurs above oil in the Cleveland sand in the Wildhorse pool. The initial yield of the wells that produced oil from the Cleveland sand ranged from less than 10 barrels to 150 barrels a day, and in many wells was less than 25 barrels a day. The Cleveland sand was not studied in detail, but the well records indicate that it is extremely lenticular in its distribution. Probably additional wells with relatively small yields could be found in the Cleveland sand in the Wildhorse field.

Burgess sand-Mississippi lime zone.-Oil and gas are produced at many places in Osage County from beds that occur at or near the contact of the Mississippi lime and the overlying Cherokee shale. Locally the oil and gas deposits are found in a sandstone known as the Burgess sand, which occurs at the base of the Cherokee shale. More commonly, however, the oil and gas occur in the uppermost beds of the Mississippi lime. It is impossible to distinguish these beds in the well $\log$ s, and consequently they are treated together here. Only about 30 wells, in widely separated places in this township, have yielded oil or gas in commercial amounts from the Burgess sandMississippi lime zone. Well records in several places in T. $22 \mathrm{~N}$., R. 10 E., indicate that the oil and gas occur in the uppermost beds of the Mississippi lime rather than in the Burgess sand, and in a few places also occur 30 to 50 feet below the top of the Mississippi lime. A microscopic examination of drill cuttings showed that

\footnotetext{
Since this report was prepared this well was deepened into the Mississippi lime, from which it again flowed wild for several days. Later it produced oil at a rate of 2,400 barrels a day and gas at a rate of $4 \frac{1}{2}$ million cubic feet a day, but a few months later it yielded mostly water.
} 
wells in sec. 18 found oil in beds composed largely of chert that forms the uppermost beds of the Mississippi lime. A recently completed well drilled by the Pure Oil Co. in the northeast corner of sec. 19 (well 1-A on pl. 1) found a large flow of oil and gas in beds that are 75 feet below the top of the Mississippi lime. ${ }^{5}$ Also, two wells in the NE1/4 sec. 9 produced oil at a high initial rate from beds that lie 30 to 60 feet below the top of the Mississippi lime. Several other wells in the township had shows of oil in beds that occur 30 to 40 feet below the top of the Mississippi lime, and a few wells had shows of oil from beds that are about 200 feet below the top.

Simpson formation and Siliceous lime.-Only a thin northwardtapering wedge of the Simpson formation as defined by Luther White ${ }^{6}$ is present in this part of Osage County. It consists mainly of quartz sand that contains many rounded grains, some green shale, and locally beds of dolomite. The Siliceous lime, which underlies: White's Simpson formation, consists mainly of sandy dolomite and limestone, some beds of which are very cherty. Oil occurs in these beds only in secs. 1, 2, and 11, in one well in sec. 5, and in secs. 32, 33 , and 34 in the Wildhorse field. It was not definitely determined whether the main oil-bearing beds occur in the Simpson formation or in the Siliceous lime, for a microscopic examination of drill samples from these beds was not made except of those from the well in sec. 5. There some oil was found in sand in the Simpson formation, but the main oil flow comes from the uppermost beds of the Siliceous lime.

Skinner sand.-The Skinner sand, which occurs in the uppermost third of the Cherokee shale, is present only locally in this township. The sand is recorded in the logs of about one-fourth of the wells. It yields oil in a small area in the $\mathrm{E} 1 / 2$ sec. 14 and in a somewhat larger area in secs. 26 and 27 . The sand, whose maximum thickness is about 40 feet, lies at a depth of about 1,500 feet in sec. 14 and 1,700 feet in secs. 26 and 27. The initial yields of the wells in sec. 14 ranged between 15 and 40 barrels of oil a day each, and of those in secs. 26 and 27 between 10 and 95 barrels. Shows of gas and oil were recorded in the Skinner sand at several localities outside these two small oil fields.

Other oil-and gas-bearing beds.-One well (No. 2 on pl. 1) in the $\mathrm{NE} 1 / 4$ sec. 19 is reported to have produced a little more than 750,000 cubic feet of gas a day from the Big lime, and one well (No. 23 on pl. 1) in the SE $1 / 4$ sec. 18 is reported to have produced a small amount

\footnotetext{
'In a short time well 1-A yielded only water and was abandoned.

"White, L. H., Subsurface distribution and correlation of the pre-Chattanooga ("Wilcox" sand) series of northeastern Oklahoma: Oklahoma Geol. Survey Bull. 40, vol. 1, pp. 23-24, 29-32, 1928.
} 
of oil from the Oswego lime. These beds yielded small shows of oil and gas in several other places. Oil-bearing beds in the Big lime and Oswego lime have been made to yield commercial amounts of oil in several places in Osage County by treating them with acid. The Layton sand, which occurs in the upper part of the Coffeyville formation, a few feet below the Hogshooter limestone, has yielded a small amount of oil in one well in the NW1/4 sec. 33. All the wells nearby were drilled through the Layton sand, however, and completed as oil producers in deeper beds.

\section{STRUCTURE AND DEVELOPMENT}

T. 22 N., R. 10 E., contains several pronounced domes and anticlines that greatly modify the regional westerly dip of the rocks, which prevails in this part of Oklahoma. The principal structural features shown on plate 1 are the westward-trending Wildhorse anticline, in the southern part of the township, on which are superposed two pronounced domes; the large North Wildhorse dome, whose crest is in the northwestern part of sec. 20 ; an anticline that trends southwestward through parts of secs. $1,2,11$, and 14 ; an anticline that trends westward through secs. 25, 26, and 27 ; and two deep synclines, one of which crosses secs. 7, 8, and 17 and the other crosses secs. 30, 29, 20, 21, and 22. All the main structural features shown by the map (pl. 1) are similar with minor modifications to those shown by the structure-contour map of the exposed beds prepared by Wood.? The folds have greater structural relief on the buried rocks than on the surface beds, however, and the crests of the domes on the buried rocks are not directly beneath the crests on the surface beds. Also, a northwestward-trending fault that displaces the surface beds a little more than 50 feet vertically in secs. 32 and 29 is shown on Wood's map but is not shown on the structure map of the buried rocks (pl. 1). The fault was omitted from plate 1 because the data are insufficient to show whether it cuts the deeply buried rocks.

Wildhorse anticline.-The crest of the largest anticline in the township, called here the Wildhorse anticline after the oil field which lies on it, trends westward from the W1/2 sec. 35 into the $W^{1 / 2}$ sec. 32 . Two pronounced domes, a little more than a mile apart, are superposed on the anticline. The structural relief of the Oswego lime is a little more than 100 feet on the main anticline and is about 80 feet on each of the individual domes. The anticline is terminated on the northwest, west, and south by deep synclines. The deep syncline that lies south of the anticline is in the northern part of the adjacent township on the south. The exposed beds in the NE1/4 sec. 32, near

T Wood, R. H., Unpublished map of parts of the Hominy quadrangle, in U. S. Geological Survey fles. 
the crest of the west dome, are cut by a northwestward-trending fault and are displaced vertically more than 50 feet. $^{8}$ If additional wells are drilled in the central part of the NE1/4 sec. 32 the subsurface mapping as shown on plate 1 may need to be modified.

Oil is produced on the Wildhorse anticline from five beds, ranging upward from the Siliceous lime to the Layton sand. The main oil-producing beds are the Bartlesville and Cleveland sands. The Bartlesville sand yields oil throughout a structural range of 250 feet. It is noteworthy that the wells having the largest initial yields are structurally low on the flanks of the anticline. That the occurrence of oil in the Bartlesville sand in the Wildhorse field is controlled by the lensing out of the sand or by the lenticular character of the permeable parts of the sand body rather than by the structural attitude of the beds is suggested by the facts observed here and by the nature of the occurrences of oil in the Bartlesville sand elsewhere in Osage County. Oil in the Cleveland sand occurs along the crest and on the flanks of the anticline through a structural range of 200 feet. Oil occurs also in this sand structurally low in a broad syncline in the $\mathrm{NE} 1 / 4$ sec. 35 and the $\mathrm{NW} 1 / 4$ sec. 36 . These facts suggest that in the Cleveland sand, as well as in the Bartlesville, the anticlinal fold is not the dominant factor in localizing the oil.

Rocks of Ordovician age that may include beds in the Simpson formation of Luther White and in the Siliceous lime yield oil in several wells on the east dome and in one well on the west dome. The drillers' logs indicate that the oil occurs in the Simpson formation, which according to White ${ }^{0}$ is 75 to 100 feet thick in sec. 33 , where several wells have penetrated it and entered pre-Cambrian rocks. The possibility that the oil occurs in the uppermost beds of the Siliceous lime exists, however, but was not determined because samples of the oil-bearing beds from the producing wells were not available for microscopic examination. The initial daily production of the wells is reported to have ranged from less than 100 barrels of oil to several thousand barrels. Three of the six wells on the west dome that penetrated these beds struck pre-Cambrian rocks, commonly called "granite," at shallow depths. Well 26 , in the NW1/4 sec. 33 , encountered "granite" at a depth of 2,622 feet, according to the driller's log. Wells 18,19 , and 20 , in the $\mathrm{NE} 1 / 4$ sec. 32 , encountered granite at depths of $2,217,2,387$, and 2,267 feet, and the identification of the preCambrian rocks was made from drill samples. ${ }^{10}$ The Siliceous lime is absent in wells 18 and 20, and the Simpson formation rests directly

\footnotetext{
${ }^{8}$ Wood, R. H., op. cit.

- White, L. H., Subsurface distribution and correlation of the pre-Chattanooga ("Wilcox" sand) series of northeastern Oklahoma: Oklahoma Geol. Survey Bull. 40, vol. 1, p. 25 1928.

${ }^{10}$ White, L. H., op. cit., p. 25.
} 
on the pre-Cambrian rocks, according to White; the Siliceous lime appears to be less than 150 feet thick in well 19.

A few wells in the Wildhorse field produce oil from the Burgess sand-Mississippi lime zone. Most of them had initial yields of less than 25 barrels a day. A few wells produced initially more than 100 barrels of oil a day. The yields of wells from these beds commonly have a wide range. The occurrence of oil or gas in the Burgess sand-Mississippi lime zone at several localities on the Wildhorse anticline indicates that wells producing oil from the Bartlesville sand should be drilled into these beds before they are abandoned. This requires that the wells be deepened about 100 feet.

The Layton sand produces oil in only one well (well 24 , in the $\mathrm{NW}: 1 / 4 \mathrm{SW} 1 / 4 \mathrm{NW}^{1 / 4}$ sec. 33 ; the well is shown without a colored overprint on pl. 1) and is therefore of relatively little importance here.

North Wildhorse dome.-The prominent dome whose crest is near the northwest corner of sec. 20 has a structural relief of approximately 100 feet on the Oswego lime. The North Wildhorse oil field is on this dome. Oil is produced here mainly from the Bartlesville sand. The well records indicate, however, that the Bartlesville sand pinches out on the east, south, and west flanks of the dome. Several wells yield oil from the Mississippi lime. Operators reported that no Burgess sand occurs here. One well produces oil from the Oswego lime, and one well, now abandoned, produced gas from the Big lime. Several wells that produced oil for a time from the Bartlesville sand have been deepened into the upper beds of the Mississippi lime, where they have found additional oil. The daily yields from the wells in the Mississippi lime have been small with the exception of well $1-\mathrm{A}$, in the northeast corner of sec. 19, which had an initial yield of about 1,000 barrels of oil a day. ${ }^{11}$ The oil in this well was found in beds that lie 75 feet below the top of the Mississippi lime. The other wells found oil in the uppermost beds, or at least not more than 20 to 25 feet below the top of the Mississippi lime. Other Bartlesville sand producers in secs. 17, 18, 19, and 20 should be deepened 100 feet into the Mississippi lime before the wells are abandoned.

The Simpson formation of White and the uppermost beds of the Siliceous lime have been tested in well 13 , in the southeast corner of sec. 18 , and well 2 , in the $\mathrm{SE} 1 / 4 \mathrm{SW} 1 / 4 \mathrm{SW} 1 / 4$ sec. 17 , but yielded no oil or gas. The Simpson formation in well $13^{12}$ contains a bed of sand 30 feet thick and a few thin beds of green shale, and the uppermost

11 Well 1 , in the northwest corner of sec. 20, was recently deepened into the Mississippi lime and vielded oil at the rate of 2,400 barrels a day and gas at the rate of $4 \frac{1 / 2}{m}$ illion cubic feet a day. After a few weeks, however, it yielded mostly Water,

${ }^{23}$ Cram, I. H. (Pure Oil Co.), oral communication based on microscopic examination of well samples. 
beds of the Siliceous lime are composed of dolomite and very cherty limestone. Although the failure of these two wells to yield oil has discounted appreciably the expectation for oil here in the Ordovician rocks, there remains a possibility that oil is present in these rocks in the NW1/4 NW1/4 sec. 20 and the $\mathrm{NE}^{1 / 4} \mathrm{NE}_{1 / 4}$ sec. 19.

Anticline in secs. 1,2,11, and 14.-An anticline with three small domes superposed along its crest trends southwestward across parts of secs $1,2,11$, and 14 . It has a structural relief of about 75 feet on the Oswego lime. The two small subsidiary domes that occur near each end of the anticline are established by data supplied by wells, but the middle dome, in the $\mathrm{NE} 1 / 4$ sec. 11 , is somewhat speculative.

Gas has been found in the Bartlesville sand on the anticline in several wells whose initial daily yields ranged from 500,000 to $18,000,000$ cubic feet. Oil was found in the upper beds of the Ordovician in five wells on the north dome and in one well on the south dome. All these wells have been abandoned. The initial yields of two of the wells on the north dome were 150 and 400 barrels of oil a day, according to the well logs. The yields of the other wells are not shown. Well samples of the oil-bearing beds were not available for microscopic examination to determine whether the oil occurs in the Simpson formation or in the Siliceous lime. The drillers' logs indicate that the oil was found in the Simpson formation in some wells and in the Siliceous lime in others. Additional oil might be obtained in these beds on the crest of the dome near the center of the $W 1 / 2 \mathrm{NE} 1 / 4$ sec. 11. Also, there is a possibility of finding gas in the Bartlesville sand and oil in the Mississippi lime here.

Other domes.-The large dome whose crest is in the W1/2 sec. 10 has a structural closure of a little more than 40 feet on the Oswego lime. Two wells on the dome produced oil from the Mississippi lime. The oil in well 11 , which was produced initially at the rate of 450 barrels a day, was found in several beds that occur 30 to 60 feet below the top of the Mississippi lime. Well 1, in the southeast corner of the NE1/4 sec. 9, found oil 30 to 45 feet below the top of the Mississippi lime. The well blew itself in and is reported to have produced initially at an estimated rate of 6,000 barrels of oil a day. Well 10 , in the NE $1 / 4 \mathrm{SE}_{1} / 4 \mathrm{NE} 1 / 4$ sec. 9, had shows of oil and gas in the Bartlesville sand and shows of oil in the Mississippi lime and produced 5 to 10 barrels of oil a day from a sand that probably belongs to the Simpson formation. Several wells on the dome found gas in the Bartlesville sand, but they were not completed as gas wells. The entire Simpson formation and the uppermost beds of the Siliceous lime appear to have been tested in three and possibly in four of the wells on the dome. The three wells are well 1 , on the center of the west line of the SW $1 / 4 \mathrm{NE} 1 / 4$ sec. 10 ; well 1 , on the center of the 
north line of the SW $1 / 4$ sec. 10 ; and well 9 , in the southeast corner of sec. 4. The fourth well, which doubtfully tested the Siliceous lime, is well 10 , in the $\mathrm{NE} 1 / 4 \mathrm{SE} 1 / 4 \mathrm{NE} 1 / 4$ sec. 9 . Well 1 , in the northeast corner of the SE1/4 sec. 9, and well 5-1, in the southwest corner of the SE1/4 sec. 4, tested the uppermost beds in the Simpson formation, according to the well logs. None of the wells that penetrated the entire Simpson formation and the uppermost beds of the Siliceous lime are on the crest of the dome, however. A structure-contour sketch of the top of the Mississippi lime, which was prepared but not reproduced here, shows (1) that the crest of the dome on that bed is near the southwest corner of the NW1/4 sec. $10 ;(2)$ that the top of the Mississippi lime is at least 30 feet lower structurally in the dry hole in the center of the north line of the SW1/4 sec. 10 than on the crest of the dome; (3) that it is 80 feet lower in the dry hole in the SW $1 / 4 \mathrm{NE} 1 / 4$ sec. 10 and 35 feet lower in the dry hole in the southeast corner of sec. 4 than on the crest of the dome. If an additional well is drilled on the dome to test the Ordovician beds the available data indicate that it should be located in the southwest corner of the NW1/4 sec. 10 and should be drilled to a depth of 2,300 feet before abandonment.

The small dome in the SE1/4 sec. 5 appears to hold some prospective value for additional oil in the Ordovician rocks. The oil-producing well in the southwest corner of the NW1/4 SE $1 / 4$ sec. 5 yielded initially 140 barrels of oil a day. It is reported that some oil was found in sand in the Simpson formation and that additional oil was found in the uppermost beds in the Siliceous lime. This well has been treated with acid at least five times during the last 3 years. The dry hole in the northeast corner of the SE1/4 SW1/4 sec. 5 had a show of oil in beds that appear to be in the Simpson formation. These beds were acidized but failed to yield enough oil to make a producing well. Additional producing wells might be obtained in the $\mathrm{SEx} / 4$ sec. 5 .

The anticlinal nose that trends northeastward through sec. 6 is a prong of a sharply folded dome whose crest is in the $\mathrm{S} 1 / 2$ sec. 1 of the adjacent township on the west. Oil and gas are produced from the Bartlesville sand and oil is produced from Ordovician beds on the dome outside of this township. Three Bartlesville sand wells that had initial yields ranging from 15 to 50 barrels of oil a day Ere along the east boundary of the $\mathrm{SE} 1 / 4$ sec. 1, T. 22 N., R. 9 E. 'These wells were drilled in 1926 and are still producing oil. The drilling date and yield of the Bartlesville sand well in the SW1/4 sec. 6 are not known. This well is an east offset to the northernmost of the three producers just mentioned. It appears probable, therefore, that additional Bartlesville sand wells could be had south and east of the lone producer in the southwest corner of the 
NW $1 / 4 \mathrm{SW}^{1} / 4$ sec. 6 . The dry hole in the southwest corner of the NW $1 / 4$ sec. 6 found gas in the Bartlesville sand, but the yield was not reported on the log.

The small dome in the southern part of sec. 16 and the northern part of sec. 21 has a structural relief of about 25 feet $^{13}$ on the exposed beds and somewhat greater structural relief on the Oswego lime. The dome appears to have less prospective merit for oil and gas than other domes in the township, because it is in a region that is structurally low.

The small domes in the NE1/4 sec. 26 and the NE1/4 sec. 27 , shown on plate 1 , are worthy of mention. One well on the dome in sec. 26 has been drilled into the Siliceous lime, and other wells found oil in the Bartlesville sand. A dry hole has been drilled into the uppermost beds of the Mississippi lime on the dome in sec. 27. The subsurface structure-contour mapping of the dome in sec. 26 is supported by the occurrence of a pronounced dome in the surface beds: ${ }^{14}$ The crest of the dome in the surface beds is near the center of the south line of the $\mathrm{NE} 1 / 4$ sec. 26 . Less confidence should be placed in the mapping shown on plate 1 for the $\mathrm{NE}_{1} / 4$ sec. 26 than elsewhere. in this township, because altitudes of the datum bed (Oswego lime). were not available for many wells. If an additional well is to be drilled here to test the Ordovician beds the geologic structure of the subsurface beds should be even more thoroughly investigated than was done for the preparation of plate 1 .

\section{RECOMMENDATIONS}

The investigation of this township indicates that additional oil may be found in the Bartlesville sand in the E1/2 sec. $32, \mathrm{~W} 1 / 2$ and $\mathrm{SE}^{1} / 4$ sec. $33, \mathrm{SW} 1 / 4$ sec. $13, \mathrm{NW}^{1} / 4$ sec. $24, \mathrm{NE} 1 / 4$ sec. 23 , and $\mathrm{SW} 1 / 4$ sec. 6. Only small yields are to be expected. Oil in the upper beds. of the Mississippi lime may be found by deepening Bartlesville sand' producers in many places in the Wildhorse and North Wildhorse: fields. Additional oil wells may be drilled into beds of Ordovician age in the $\mathrm{SE} 1 / 4 \mathrm{sec}$. 5 . These beds remain untested in the southwest corner of the $\mathrm{NW}^{1} / 4$ sec. 10 , on the highest part of the dome there, and in the NW1/4 NW1/4 sec. 20 and the $\mathrm{NE}^{1} / 4 \mathrm{NE}^{1} / 4$ sec. 19 , on the: crest of the dome there, although they have been proved to be barren of oil and gas near the latter locality by the dry hole in the SE1/4 SE $1 / 4$ sec. 18. The small dome in the $\mathrm{W}_{1}^{1 / 2} \mathrm{NE} 1 / 4$ sec. 11 may merit a test of the Ordovician beds, but only after a thorough geologic investigation of the area indicates that the hypothetical contours shown on

13 Wood, R. H., Unpublished map of parts of the Hominy quadrangle, in U. S. GeologicaI Survey files.

${ }^{14}$ Idem.

$41865-38-3$ 
plate 1 truly represent the structural features. However, the prospect of finding gas in the Bartlesville sand is good and that of finding oil in the Mississippi lime is fair.

The oil pools in the Bartlesville sand and Cleveland sand. will probably be subjected to repressuring and water-flooding operations at some future date. The shallower depth of the Cleveland sand makes it the more attractive for investigation for repressuring and water flooding. The high cost of a flooding project in a reservoir bed that lies at the greater depth of the Bartlesville sand will probably delay such an undertaking until the oil commands a higher price than at present.

\section{T. 23 N., R. 10 E.}

T. 23 N., R. 10 E., is in east-central Osage County, in the midst of a region that contains many oil fields that produce oil mainly from the Bartlesville sand. This sand has yielded oil in 133 wells out of a total of 164 oil- or gas-producing wells in this township. Oil is obtained in large amount from Ordovician beds also, mainly in two small areas in the western half of the township. A feew wells in the eastern part of the township produce oil at a small daily rate from the Burgess sand-Mississippi lime zone.

The geologic study of this township revealed the existence of several untested areas that are prospectively valuable for oil and gas. The depth to the main oil-bearing beds in the eastern part of the township is about 1,750 feet and in the two principal oil fields in the western part of the township about 2,550 feet.

A few wells were drilled in T. 23 N., R. 10 E., in 1905 and 1906 but failed to find oil or gas. Both oil and gas were found in the southeast quarter of the township in 1913, but not many wells were drilled until 1919 to 1922 , when most of the oil- and gas-producing area in the east half of the township was developed. The wells in the small oil field that surrounds the quarter corner between secs. 17 and 20 were drilled in 1926 and 1927, although the four wells immediately southwest of the field had been drilled several years prior to this date, and the dry hole farther southwest, in the NW $1 / 4$ SE $1 / 4$ sec. 19 , had been drilled in 1905 . The small group of oil wells in sec. 32 was drilled in 1929 and 1930.

Most of the wells in the east half of the township yielded initially less than 50 barrels of oil a day; several, however, produced initially 200 barrels or more a day, and one well in sec. 25 had an initial production of 680 barrels a day. Two wells in sec. 17 each had initial daily yields of more than 600 barrels of oil, and one well in sec. 32 produced initially 350 barrels a day. Other wells nearby produced initially at a low rate, however. The oil reservoir beds in 
the small field in the $\mathrm{S} 1 / 2$ sec. 17 and $\mathrm{N} 1 / 2$ sec. 20 were treated with acid early in 1934, and those in the small field in sec. 32 were treated in 1933; this treatment greatly increased the yield of the wells in both fields.

The subsurface geologic investigation of this township was made in part by J. H. Hengst in 1935 and was completed in 1936 by N. W. Bass, L. E. Kennedy, and W. R. Dillard.

\section{OIL- AND GAS-PRODUCING BEDS}

Oil or gas has been produced in this township from five beds rang: ing from the uppermost part of the Siliceous lime, of Ordovician age, at a depth of about 2,550 feet in the western half of the township, to the Squirrel sand, of Pennsylvanian age, at a depth of about 1,450 feet in the southeastern part of the township. The Bartlesville sand, which occurs in the Cherokee shale about 250 feet below the Squirrel sand, has yielded oil and minor amounts of gas in many wells in the eastern third of the township. The uppermost part of the Siliceous lime has yielded relatively large amounts of oil in two small areas in the western third of the township, and there are fair prospects of discovering additional oil pools in these beds. The Skinner and Squirrel sands, which bear considerable oil and gas elsewhere in Osage County, have yielded oil or gas in very few wells in this township.

Bartlesville sand.-The Bartlesville sand, a lenticular bed in the lower part of the Cherokee shale, occurs at a depth of about 1,750 feet in the eastern third of the township and a little more than 2,000 feet in the western third. It is composed characteristically of fine, fairly well sorted angular to subangular quartz grains, associated with a few grains of mica and other minerals, including feldspar. It ranges from a few feet to more than 75 feet in thickness and is locally absent. In northeastern Oklahoma the oil-producing areas in the Bartlesville sand characteristically occur in narrow belts, many of which have a north-northeast alinement. Such belts are not clearly discernible in T. 23 N., R. 10 E., possibly because the oil- and gasproducing areas have not been completely defined by the drilling of wells. In fact, except for the oil field in secs. 12 and 13, the distribution of the wells that produce oil from the Bartlesville sand outlines many irregular-shaped oil-bearing areas that are unsystematically arranged. Microscopic examination by Constance Leatherock of samples from a few wells in this township showed that drillers' logs record sand at the position of the Bartlesville sand in some localities where the beds are really sandy shale incapable of serving as a reservoir bed for oil.

The Bartlesville sand supplies oil to more wells and to a larger area than all the other beds combined. This sand has produced oil or gas 
in 133 wells, most of which are in the eastern third of the township. Most of the wells had initial yields of less than 50 barrels of oil a day. Several wells, however, produced initially 200 barrels or more a day. Although wells in this region commonly produce oil from the Bartlesville sand at a relatively low daily rate, they yield oil for many years. It is significant that, although some of the 42 wells in secs. 12 and 13 were drilled as early as 1918, and most of them had been drilled by the end of 1923, all but 7 are still producing. On the basis of the data at hand it appears probable that additional wells with small daily yields of oil from the Bartlesville sand could be drilled in many areas in the southeastern third of the township.

Siliceous lime.-The uppermost beds of the Siliceous lime have yie]ded large amounts of oil on two small domes in the western part of the township. The oil-bearing beds, as shown by microscopic examination of cuttings from wells in secs. 17 and 20, consist of cherty dolomite and limestone that is in part oolitic. They underlie a thin sequence of beds of green shale and sandstone that appears to form the northernmost thin wedge of the Simpson formation as defined by Luther White. ${ }^{15}$ The Simpson formation thickens southward and thins northward ${ }^{10}$ from this locality and is absent a few miles to the north. Only 19 wells outside of the two oil fields in secs. 17, 20, and 32 have penetrated the upper part of the Siliceous lime, and none have penetrated it more than 100 feet. Few data indicating the total thickness of the Siliceous lime in this township are available. It is only 55 feet thick in well 9 , in the northwest corner of the SE $1 / 4 \mathrm{NW} 1 / 4$ sec. 36 , where, according to microscopic examinations of well cuttings by geologists of The Texas Co., pre-Cambrian granite was struck 55 feet below the top of the Siliceous lime. The small thickness of the Siliceous lime is probably of only local extent, however. This well is near the crest of a sharply folded dome, where pre-Cambrian rocks occur at shallow depth. Elsewhere in Osage County where a similar relationship exists deep wells on the crest of a dome and other wells nearby but away from the crest show that the local relief on the pre-Cambrian surface is large and that the Siliceous lime thickens rapidly away from the crest of the dome. The total thickness of the Siliceous lime is known to range from less than 100 feet near the crest of a fold to nearly 1,000 feet, and possibly more, only a few miles away.

Other oit- and gas-bearing beds.-The uppermost beds of the Mississippi lime have yielded oil in 12 wells and gas in 1 well. Most of the oil wells produced initially less than 50 barrels of oil a day,

${ }^{15}$ White, L. H., Subsurface distribution and correlation of the pre-Chattanooga ("Wilcox" sand) series of northeastern Oklahoma: Oklahoma Geol. Survey Bull. 40, vol. 1, pp. 23-24, 29-32, 1928.

${ }^{16}$ Idem, map 2. 
although well 2 , in the center of the east line of the $\mathrm{NE}^{1 / 4} \mathrm{NE} 1 / 4$ sec. 23 , produced initially 180 barrels. Additional oil could probably be found in these beds by deepening the Bartlesville sand producers in sec. 23 and other places in the eastern half of the township. The daily yields, however, will probably be small. That oil may be found 100 feet or more below the top of the Mississippi lime is a possibility. Oil occur's deep in the Mississippi lime in parts of two fields in the adjacent township on the south and in one locality in T. 22 N., R. 11 E., which corners T. 23 N., R. 10 E., on the southeast.

The Skinner sand occurs locally in the Cherokee shale about 40 feet above the Pink lime and 150 feet above the Bartlesville sand. It is absent in most wells except those in sec. 35 ; here shows of gas are recorded in the sand in several wells and a commercial yield of gas is reported in well 405 . The gas-bearing sand is 8 feet thick in well 405 , and the total thickness of the Skimner sand in sec. 35 is commonly from 5 to 20 feet. The Squirrel sand occurs from a few feet to 30 feet below the top of the Cherokee shale and about 75 feet above the Skinner sand. It is separated from the Skinner sand by a sequence of beds that contains the Verdigris lime, which is 5 to 10 feet thick. The Squirrel sand ranges from 5 to 50 feet in thickness and occurs in some localities in two benches separated by shale and elsewhere as a solid bed of sand. It is present only locally. It yielded gas in five wells, two of which have been abandoned, on the dome in secs. 25 and 36 . The initial production of the wells ranged from 8 to 35 million cubic feet of gas a day.

\section{OIL YIELDS}

According to records of the Osage Indian Agency the Bartlesville sand in secs. 12 and 13 yielded 876,746 barrels of oil from July 1918, the discovery date of the oil pool, through July 1936. The wells in the field are spaced at intervals of 550 feet. Each well is assumed, therefore, to drain oil from 6.4 acres. On this basis the yield to the acre was 3,261 barrels of oil up to July 31, 1936. Thirty-five wells in secs. 12 and 13 are still producing oil. The lone oil well in the northeast corner of sec. 17 discovered oil in the Bartlesville sand in May 1923. It had produced 64,419 barrels of oil by the end of 1936 and is still producing about 10 barrels of oil a day. Another lone well whose first oil was run in October 1923 is in sec. 8 and yields oil from the Bartlesville sand but in smaller amount than the well in sec. 17. On September 30, 1936, at the end of its 13th productive year, the total yield from this well was 20,000 barrels of oil.

The wells in the $\mathrm{S} 1 / 2$ sec. 17 and the N1/2 sec. 20 that yield oil from the Siliceous lime produced a total of 378,306 barrels of oil between October 1926 and December 31, 1936. Assuming that each well 
drained 6.4 acres, the average yield to the acre through 1936 was 7,389 barrels of oil.

Oil from the Siliceous lime in sec. 32 was produced first in September 1929. The total production through December 31, 1936, was 208,400 barrels of oil, and the average yield to the acre was 6,512 barrels.

The rate of yield of the wells in secs. 17 and 32 has been greatly increased by treating the oil-bearing beds in the uppermost part of the Siliceous lime with hydrochloric acid. The four wells in the SE1/4 sec. 17, which were given acid treatment in 1934, yielded an average total of 266 barrels a month in the year prior to treatment and an average of 3,864 barrels of oil a month during the $2 \frac{1}{2}$ years following treatment. The wells produced more oil in the $1 \frac{1}{2}$ years following acid treatment than they had produced in the 6 years prior to treatment. The wells in sec. 32 , which also produce oil from the Siliceous lime, responded almost as well as those in sec. 17. Well 1 , in the SW $1 / 4$ sec. 32, had produced a total of 2,961 barrels of oil between March 1930, its discovery date, and the end of 1933. During the succeeding 2 years and 7 months, after treatment with acid, the well produced 40,594 barrels of oil.

Oil was discovered in the NW1/4 sec. 32 in September 1929, and 57,123 barrels of oil had been produced from the lease by September 30,1933 . The average yield from the tract was about 500 barrels of oil a month during the first 9 months of 1933. Acid treatment of the reservoir rocks was begun in October 1933. During the succeeding 12 months 58,000 barrels of oil was produced from the lease, or more than the total production during the preceding 4 years. A total of 104,841 barrels of oil was produced from the lease between October 1933, when the first well was acidized, and December 31, 1936.

It is needless to point out the advisability of treating the reservoir beds with acid in other wells that find oil in the Siliceous lime. The Bartlesville sand has been treated with acid in a few wells in Osage County outside this township but in most localities has failed to respond with increased yields of oil or gas. Acid treatment of the oil-bearing beds in the Mississippi lime has increased the yield of oil in some places and failed to do so in other places.

\section{STRUCTURE AND DEVELOPMENT}

The eastern part of T. 23 N., R. 10 E., occupies the western margin of a belt of country that trends northeastward across eastern Osage County and is characterized by relatively pronounced structural relief. The western two-thirds of the township lies in another belt that borders the folded belt on the northwest and is characterized by 
a relatively uniform westerly dip of the beds. ${ }^{17}$ Locally, however, the regional westerly dip of the beds across this western belt is interrupted by small sharply folded domes, some of which are in the western part of T. 23 N., R. $10 \mathrm{E}$. In the areas where many wells have been drilled, abundant information, including an unpublished structure-contour map prepared by Wood ${ }^{18}$ for the Geological Survey, shows that the main structural features of the exposed rocks are present and are more pronounced in the buried rocks. In the preparation of the subsurface structure contours on the accompanying map (pl. 1) this apparent relationship between the surface and buried rocks has been projected into areas that contain few datum points on the buried rocks.

The main structural features in T. 23 N., R. 10 E., include (1) the large, somewhat complex dome in the southeastern part of the town: ship, (2) the western flank of the Hardy dome in secs. 1, 12, and 13; whose crest is in the adjacent township on the east, and (3) the small domes in secs. $2,4,17,20$, and 32 .

The small domes in secs. 4 and 20 may contain undiscovered oil pools in the Siliceous lime. They are structurally similar to two domes nearby, one in secs. 17 and 20 and the other in sec. 32, that have yielded large amounts of oil from the uppermost beds of the Siliceous lime which were encountered at depths of about 2,500 feet. Wood's structure-contour map ${ }^{19}$ of the surface rocks shows a southwestward-trending nose overlying the south flank of the subsurface dome in sec. 17 and a low dome overlying the subsurface dome in sec. 32. In sec. 32 the crest of the dome on the surface beds, as shown on Wood's map, lies a short distance northeast of the crest of the dome on the Oswego lime as shown on plate 1.

The untested dome in sec. 4 is overlain by a dome-shaped fold in the surface rocks, on which the beds are more steeply folded than they are in sec. 32. The crest of this dome in the surface beds is near the west line of the $\mathrm{SE}^{1} / 4$ sec. 4 , a short distance east of the crest of the dome in the Oswego lime as shown on plate 1. The structural relief in the surface beds is 15 feet or more. The exposed rocks form a southwestward-trending anticlinal nose in the center of the W1/2 sec. 20, overlying the subsurface dome shown on plate 1 . Each of the other domes or prominent structural noses in the Oswego lime shown on plate 1 underlies domes or noses in the surface beds as shown on Wood's structure-contour map.

${ }^{17}$ Bass, N. W., Kennedy, L. E., Dillard, W. R., and Leatherock, Constance, Subsurface geology of Osage County, Okla., United States Department of the Interior Press Memorandum 105368, p. 11, 1936.

${ }^{18}$ Wood, R. H., Unpublished map of parts of the Hominy quadrangle, in Geological Survey files.

19 Idem: 
Should oil be found in either of the domes in secs. 4 and 20 the value of the following structural features will be enhanced: The untested structural nose extending southward into the $\mathrm{NW} 1 / 4$ sec. 29 , the structural terrace in the $W^{1 / 2}$ sec. 3 , and the dome that occupies parts of secs. 16 and 17. The small dome in sec. 2 has been tested by the dry hole in the northwest corner of the $\mathrm{SE} 1 / 4$ of the section, which penetrated the uppermost beds of the Siliceous lime. There is a possibility that the crest of this dome lies northwest of its position shown on plate 1. The finding of oil in the other dones just described would justify a thorough investigation of the structural attitude of the rocks in sec. 2.

More than 100 wells have been drilled on or very near the large complex dome in the southeastern part of the township. Eighty wells yielded oil in the Bartlesville sand, at a depth of about 1,700 feet. Most of these wells were drilled between 1919 and 1922, and 31 of them are still producing oil. The leases that were producing oil in 1936 from the Bartlesville sand are in the $\mathrm{NE}_{1} / 4$ sec. $36, \mathrm{SW} 1 / 4$ sec. 25, and NE1/4 sec. 26. More than half of the Bartlesville sand wells yielded initially less than 50 barrels of oil a day, but nine or more wells yielded initially more than 200 barrels of oil a day. One well (well 2 , in the $\mathrm{NE}_{1 / 4} \mathrm{SW}_{1 / 4}$ sec. 25 ) is reported to have produced initially 680 barrels a day. The occurrence of oil in the Bartlesville sand appears not to be controlled here by the structural attitude of the rocks. On the basis of the information available it appears probable that additional oil could be recovered from the Bartlesville sand in several places in secs. $25,26,35$, and 36 . The initial yields of the wells will probably be small, but the production performance of the wells in the vicinity indicates that if additional oil wells are found they will probably produce oil for a long time. For example, three of the five oil-producing wells in the $\mathrm{NW}^{1} / 4$ sec. 25 , which were all drilled in 1921 and abandoned in 1936, had initial yields between 20 and 85 barrels of oil a day each. Well 4, which has not been offset to the north, west, or east, yielded initially 255 barrels of oil a day, according to the well log.

Gas. was found in the Squirrel sand at depths about 1,450 feet in five wells on the dome. The initial yields of the wells are recorded as ranging from 6 to 35 million cubic feet of gas a day. Possibly additional gas wells could be found in the Squirrel sand. The sand is lenticular, however, and therefore prospecting for it is somewhat hazardous.

Several wells on the large dome in the southeastern part of the township were drilled into the Siliceous lime. One of these wells, in the NW1/4 sec. 36, is near the crest of the dome, a location that appears to be well suited to test the oil possibilities of the Siliceous lime. 
This well encountered the Siliceous lime at a depth of 2,125 feet, continued into it 55 feet, and then entered pre-Cambrian rocks. The other wells are on the flanks of the dome. The Siliceous lime has not been tested in the $\mathrm{NW} 1 / 4$ sec. 35 nor in the $\mathrm{SE} 1 / 4$ sec. 26 , where small subsidiary domes occur on the flanks of the main dome. The fact that several wells widely distributed over the main dome have failed to find oil in the Siliceous lime indicates that these two subsidiary domes hold little promise for oil in these beds. On the other hand, it is probable that many beds of the Siliceous lime are present on these small domes but have been eroded from the crest of the main dome and therefore were not tested by the well drilled there. That these beds may contain oil in the two subsidiary domes remains a possibility until they are tested by the drill.

A total of 26 wells, 23 of which produced oil, have been drilled in the small field centering in the NE1/4 sec. 23 . Seventeen of the wells produced oil from the Bartlesville sand, and five produced oil from the uppermost beds of the Mississippi lime. At least one of the five wells (well 1 , in the northeast corner of sec. 23) found gas in these beds, with a reported volume of 5 million cubic feet a day. The initial yields of the Bartlesville sand wells ranged from 25 to 85 barrels of oil a day, and of the Mississippi lime wells from 15 to 180 barrels a day. It is probable that additional oil wells with relatively small yields of oil from the Bartlesville sand could be found in the $\mathrm{NE}_{1 / 4}$ sec. 23 . Wells producing from the Bartlesville sand should be deepened into the Mississippi lime before they are abandoned.

The Bartlesville sand oil field in secs. 12 and 13 appears to have been fairly well defined. It is possible that the oil-producing area could be expanded in the SW $1 / 4$ sec. 13 , however. Well 2, in the northeast corner of the SW $1 / 4$ sec. 13 , produced initially only 5 barrels of oil a day, according to the well $\log$, but has been producing for several years. The presence of oil-bearing Bartlesville sand both to the northeast and to the southwest of the relatively large tract in the SW1/4 sec. 13 that contains no wells or dry holes, suggests that oil-bearing Bartlesville sand may be present in that tract also. Most of the wells in secs. 12 and 13 yielded initially less than 50 barrels of oil a day, which indicates that only wells with small daily yields can be expected in the SW1/4 sec. 13 .

This oil field offers attractive possibilities for a repressuring or water-flooding project at some future date.

\section{RECOMMENDATIONS}

It is recommended that the Siliceous lime be tested for oil on the domes in secs. 4 and 20. If oil is found here the anticlinal noses 41865-38-4 
in secs. 29 and 3 should be tested also. Wells should be drilled into the Bartlesville sand in the NE1/4 sec. 17 and the NW1/4 sec. 16, south and southeast of the lone Bartlesville sand oil-producing well in the northeast corner of sec. 17. A somewhat higher price for oil than now prevails would justify the drilling of additional wells to test the Bartlesville sand and Burgess sand-Mississippi lime zone in the several tracts that lie between oil-bearing tracts in secs. 13, $23,25,26,35$, and 36 . It is advisable to deepen several wells into the Mississippi lime in each of the Bartlesville sand oil-producing tracts in the eastern part of the township before they are abandoned.

\section{T. 22 N., R. 11 E.}

T. 22 N., R. 11 E., is in southeastern Osage County, 12 miles northwest of Tulsa, which is adjacent to the southeast corner of the county. Both oil and gas are produced in this township from beds that have a wide stratigraphic range. Several places hold good prospects for the discovery of additional oil and gas.

Most of the 280 or more wells in the township were drilled between 1919 and 1926. A few wells were drilled in 1912 and 1913, and according to data on well logs a dry hole was drilled in sec. 35 as early as 1905 . The most recent drilling activity has been done in 1935 and 1936 in sec. 28, where several wells have found oil in the Siliceous lime.

The subsurface geologic investigation of this township was made in 1935 and 1936 by L. E. Kennedy, assisted by several members of a Geological Survey field party. The map of this township (pl. 1) was prepared mainly by Mr. Kennedy, assisted by Otto Leatherock.

\section{OIL- AND GAS-PRODUCING BEDS}

A study of the logs of wells in this township shows that oil or gas occur in eight beds, which are, in the approximate order of their productiveness, the Bartlesville sand including the Red Fork sand in some localities, the Burgess sand-Mississippi lime zone, the Big lime, the Ordovician rocks, the Taneha sand, the Oswego lime, and the Squirrel sand.

Bartlesville sand.-The Bartlesville sand, which occurs in the Cherokee shale at depths ranging from 1,625 to 1,750 feet, yields oil or gas in six or more localities in the township. The principal gasbearing areas are in secs. 19 and 33 . The well logs indicate that the sand is extremely variable in thickness and is absent locally; these features are characteristic of the Bartlesville sand throughout eastern Osage County. The sand ranges from a few feet to about 50 feet in thickness where it is present in the northwestern part of the township and is somewhat thicker than that in the west-central 
part of the township. The sand is between 50 and 100 feet thick in many of the wells in the small oil pool in secs. 20 and 21 . It ranges from a few feet to 175 feet in thickness in secs. 22,23 , and 26 and is between 125 and 150 feet thick in sec. 33. Beds included in the Bartlesville sand in secs. $4,5,6,8,22,23$, and 27 occur somewhat higher stratigraphically than the Bartlesville sand beds in secs. 18, 19,20 , and 21. The logs of most of the wells do not record what part of the Bartlesville sand yields oil. The logs of several wells, however, indicate that gas occurs in the upper part and oil in the lower part of the sand. The logs of some wells show oil in the uppermost part of the sand.

The initial production of wells that produce oil from the Bartlesville sand ranged from 3 to 125 barrels of oil a day; the average initial production was about 40 barrels. The average initial production of the Bartlesville sand wells in secs. 4, 5, 6, 18, 19, 20, and 21 ranged from 35 to 55 barrels of oil a day, and the average of the wells in secs. 22 and 23 ranged from 5 to 20 barrels. The gas wells in secs. 5 , 18,19 , and 33 , had initial daily yields between 1 and 32 million cubic feet of gas.

Red Fork sand.-A sand that locally contains oil and gas occurs in the northern two-thirds of the township at depths ranging from 1,500 to 1,650 feet, at the stratigraphic position of the Red Fork sand of southern Osage County. It is difficult to differentiate this sand from the underlying Bartlesville sand in a few localities where the well logs show a continuous body of sand extending from the normal stratigraphic position of the Red Fork sand downward through the position of the Bartlesville sand. Elsewhere a shale bed, which locally contains a thin bed of limestone (Inola?) separates the Bartlesville and Red Fork sands. The thickness of the Red Fork sand ranges from 15 to 40 feet and averages about 25 feet in localities where it is separated from the underlying Bartlesville sand. The Red Fork sand is designated the oil- or gas-bearing bed on plate 1 in five wells in sec. 17 , one well in sec. 20 , and two wells in sec. 7, although the sand in those localities might be interpreted by some geologists as an upper phase of the Bartlesville. The initial yields of the gas wells producing from the Red Fork sand ranged from $1 \frac{1}{2}$ to 8 million cubic feet a day, and the initial yields of the oil wells ranged from 10 to 25 barrels a day.

Burgess sand-Mississippi lime zone.-Thirty-five wells distributed through nine sections in the northwestern third of the township have produced oil or gas from beds that occur at depths of 1,800 to 1,900 feet, either immediately above or below the contact of the Mississippi lime with the Cherokee shale. The logs of about a third of the wells record the oil- and gas-bearing beds as sand lying between shale 
above and limestone below; and the logs of other wells record the beds as sandy lime or sand from a few feet to 40 feet below the top of the Mississippi lime. It was not determined definitely whether the oil and gas occur in the Burgess sand, which forms the basal bed of the Cherokee shale in parts of Osage County, or in the upper beds of the Mississippi lime, which commonly consists of chert or cherty limestone. Drill samples of the beds were not examined. However, the $\operatorname{logs}$ indicate that the oil and gas occur in the Mississippi lime in most of the wells. Wells that found oil in the Burgess sand or Mississippi lime had initial yields ranging from 3 to 75 barrels a day and the gas wells had yields ranging from 4 to 11 million cubic feet a day. The oil wells averaged initially about 35 barrels a day and the gas wells about 4 million cubic feet a day. Well 1 , in the $\mathrm{NE} 1 / 4$ sec. 17 , which had a reported initial production of 1,200 barrels of oil a day, is unusual in that the oil occurs in beds that are 160 feet below the top of the Mississippi lime. This occurrence of oil far below the top of the Mississippi lime is similar to those in secs. 9,19 , and 20, T. 22 N., R. 10 E., where large initial yields of oil were obtained from beds that are 60 to 75 feet below the top of the Mississippi lime.

Big lime.-Beds in the uppermost 50 feet of the Big lime yield oil or gas at depths ranging from 1,090 to 1,150 feet in 22 wells in secs. 4, 5, 8, and 9. The beds are recorded by the drillers as limestone, sand, sandy limestone, or alternating beds of sand and limestone. The initial production of the oil wells ranged from 12 to 450 barrels a day and that of the gas wells ranged from 1 to 7 million cubic feet a day. The average daily yield of the oil wells was about 100 barrels and that of the gas wells about 4 million cubic feet.

Ordovician rocks.-Oil and gas occur in beds in the upper part of the Ordovician system in secs. $9,19,28,31,32,33$, and 36 at depths ranging from 2,000 to 2,200 feet. Drill samples from these beds were not studied, and without study it is impossible to differentiate accurately the beds recorded in the well logs. The Simpson formation of Luther White, which is composed of beds of sandstone, green shale, and a few beds of dolomite, commonly overlies the Siliceous lime in this part of Osage County and is the youngest formation of the Ordovician system present. Its thickness ranges from a few feet to more than 100 feet. The uppermost beds of the Siliceous lime are composed of finely crystalline dolomite, sandy dolomite, and some chert. The drillers' logs of the wells in sec. 9 that produced gas from Ordovician rocks indicate that the gas occurs mainly in the Simpson formation; but the identification of the beds without a study of drill samples is speculative. Shows of oil occur in sand in the Simpson formation in secs. 28, 33, and 34, but the oil that is produced occurs in the upper part of the Siliceous lime, according to determinations 
based on microscopic studies of drill samples made by Floyd Miller, ${ }^{20}$ of the Bay Oil Corporation. The oil-bearing bed here is composed of finely crystalline sandy brown dolomite. It occurs from 10 to 12 feet below the top of the Siliceous lime in some wells and from 20 to 22 feet below the top in other wells, according to Miller. The well logs suggest that probably the oil in secs. 36 and 33 occurs also in the uppermost beds of the Siliceous lime. The logs of the wells in secs. 19 and 31 are too indefinite to hazard a guess as to whether the oil occurs in the Simpson formation or in the Siliceous lime.

The initial production of the gas wells producing from Ordovician beds ranged from 500,000 to 10,000,000 cubic feet a day and the initial production of the oil wells ranged from 15 to 1,600 barrels a day. The average initial daily production of the gas wells was about 6 million cubic feet and that of the oil wells about 200 barrels.

Taneha sand.-Three wells, now abandoned, in the $\mathrm{E} 1 / 2 \mathrm{E} 1 / 2$ sec. 36 (shown on plate 1 without colored overprint) yielded oil from a bed encountered at a depth of about 1,800 feet that appears to represent the Taneha sand. The oil-bearing bed is recorded to be 5 to 15 feet thick and to lie about 30 feet below the Bartlesville sand and about 40 feet above the Mississippi lime. This bed is not recorded in the $\operatorname{logs}$ of wells outside this small area. Two of the three Taneha sand wells in sec. 36 had initial yields of 15 barrels of oil a day and the other one 20 barrels a day. It is possible that the well in the southeast corner of the NE1/4 sec. 36 produced oil from the Burgess sand or the uppermost beds of the Mississippi lime. The well was drilled to a sufficient depth to penetrate these lower beds, but the well $\log$ is not clear as to whether the oil occurred in the Taneha sand or in the lower beds.

Oswego lime.-One well (No. 771 on the map) in the SE $1 / 4$ sec. 33 produced initially 750,000 cubic feet of gas a day from the uppermost beds of the Oswego lime at a depth of 1,115 feet. The log of well $5-288$, in the SW1/4 sec. 9, reported a show of gas in the Oswego lime encountered at a depth of 1,215 feet.

Squirrel sand.-The Squirrel sand in the uppermost part of the Cherokee shale is present in about one-third of the wells in this township. It is recorded as ranging from 10 to 30 feet in thickness. The sand produced oil in only one well, which is in the SW1/4 sec. 17. The well had an initial yield of 15 barrels a day from sand that is 20 feet thick and was encountered at a depth of 1,235 feet.

\section{STRUCTURE AND DEVELOPMENT}

The Oswego lime (Fort Scott limestone), which is the datum bed used in drawing the subsurface structure contours on the map (pl. 1),

${ }^{20}$ Oral communication. 
lies at an average depth of about 1,250 feet in T. 22 N., R. 11 E., and has a regional westerly dip across the township which amounts to about 200 feet. The regional dip is interrupted by several pronounced anticlines and synclines. The principal structural features. are the Fox dome and the South Brown anticline, in the northwestern part of the township; the Cedar Bluff dome, in the west-central part; the Lake View dome, in the south-central part; a somewhat. hypothetical anticline in sec. 12 ; and a major syncline that extends northeastward from the southwestern part into the central part of the township. One fork of the syncline trends northward across secs. 20 and 17. These features are in the main similar to those shown by Ross' structure-contour map of the surface beds, ${ }^{21}$ which was used as a basis for interpreting the structure of the buried rocks in areas that contain only a few datum points on the subsurface beds. Faults cut the surface beds in secs. $12,13,24,33$, and 34 . The vertical displacement of the surface rocks is about 30 feet in secs. 12,13 , and 24 and about 40 feet in secs. 33 and 34, according to Ross' map. The data are insufficient to determine to what depth the buried rocks are displaced by the faults. Accordingly, no faults are shown by the subsurface structure contours.

South Brown anticline.-The South Brown anticline is a broad fold whose crest trends southward through secs. 4, 9, 16, and 17 into sec. 20. Superposed on the principal anticline are three domes, whose crests are in the SW1/4 sec. 4, the SW1/4 sec. 9, and the NE1/4 sec. 8. The South Brown anticline is only the southern portion of a much larger fold whose northern portion, the Brown anticline, lies in the adjacent township on the north. The Brown anticline is separated from the South Brown anticline by a structural saddle in the SW $1 / 4$ sec. 33, T. 23 N., R. 11 E. The subsurface structure-contour map of the South Brown anticline drawn on the top of the Oswego lime is closely similar to the structure-contour map of the surface rocks by Ross. The principal differences between the structure of the Oswego lime and that of the surface beds are that (1) the dips on the Oswego lime are steeper than those on the surface beds, (2) a dome occurs on the Oswego lime in the $\mathrm{SW} 1 / 4$ sec. 4 , but the surface beds. form a northward-plunging anticlinal nose, and (3) a low dome is present on the Oswego lime in the NE $1 / 4$ sec. 8 where the surface beds form a broad anticlinal nose. The northeastward-trending anticlinal nose in secs. 9 and 10 shown on plate 1 is interpreted largely from Ross' map, which shows a pronounced anticlinal nose here in the surface beds. It is probable that the subsurface beds in the NW1/4 sec. 10 form a dome, but the few data available here did not appear to warrant showing a dome on the map (pl. 1).

\footnotetext{
${ }^{21}$ Ross, C. S., in White, David, and others, Structure and oil and gas resources of the Osage Reservation, Oklahoma : U. S. Geol. Survey Bull. 686, pl. 30, 1922.
} 
Approximately 80 wells have been drilled on or near the South Brown anticline. Of these wells 21 produced oil or gas from the Big lime, 1 produced oil from the Squirrel sand, 6 produced oil or gas from the Red Fork sand, 32 produced oil or gas from the Bartlesville sand, 13 produced oil or gas from the Burgess sand-Mississippi lime zone, and 6 produced gas from beds that occur in either the Simpson formation or the Siliceous lime.

Most of the Big lime gas wells are near the crest of the anticline. Two of the Big lime gas wells in the $\mathrm{SE} 1 / 4$ sec. 5 , however, are on the west flank of the fold 60 feet structurally lower than the crest. The Big lime oil wells are in the $\mathrm{E} 1 / 2$ sec. 5 , where the rocks are structurally low on the northwest flank of the anticline; one oil well is near the crest of the small dome in the north-central part of sec. 8 . Plate 1 fails to show the complete history of well 1 , in the SE1/4 sec. 5. This well produced oil for a time from the Bartlesville sand; later it was deepened into the Mississippi lime, and then was plugged back to the Big lime from which it is now producing oil. The Big lime producers are about 1,100 feet deep. Nine Big lime gas wells had initial yields that ranged from 1 to 7 million cubic feet a day, and $11 \mathrm{Big}$ lime oil wells had initial yields that ranged from 12 to 450 barrels a day.

The Bartlesville sand has yielded oil or gas in several widely separated places on the South Brown anticline at depths ranging from 1,600 to 1,750 feet. The oil- and gas-producing areas are low on the flanks of the anticline. It appears probable that the structural attitude of the rocks here, as well as elsewhere in Osage County, has little or no control over the occurrence of oil in the Bartlesville sand. Of the Bartlesville sand wells 31 had initial daily yields that ranged from 8 to 114 barrels of oil and 1 had an initial yield of $51 / 2$ million cubic feet of gas,

A sequence of beds that may include the Burgess sand and the upper part of the Mississippi lime but probably includes only beds in the Mississippi lime yielded oil in a few wells in widely separated localities on the flanks of the South Brown anticline from depths of about 1,800 to 1,900 feet. The initial yields of the wells ranged from 30 to 100 barrels a day. Gas was produced at an initial rate of $4 \frac{1}{4}$ million cubic feet a day from these beds in one well in the southeast corner of the NW1/4 sec. 9 .

A well (No. 1 on pl. 1) near the center of the NE1/4 sec. 17 is reported to have produced initially 1,200 barrels of oil a day from beds that occur 160 feet below the top of the Mississippi lime. This well is unusual, because oil occurs deep in the Mississippi lime in only a few localities in Osage County. A similar occurrence was found in the northeast corner of sec. 19, and the northwest corner 
of sec. 20 , T. 22 N., R. 10 E., about 6 miles west of the South Brown anticline, where large flows of oil were obtained from beds that occur 75 feet below the top of the Mississippi lime. Two wells in sec. 9, T. 22 N., R. 10 E., obtained large flows of oil and gas from beds 30 to 60 feet below the top of the Mississippi lime.

Wells in sec. 9, on the higher part of the south dome of the South Brown anticline, produced gas from Ordovician beds encountered at depths of about 2,000 to 2,200 feet. The initial yields of the wells ranged from 500,000 to $6,500,000$ cubic feet of gas a day. It is not certain whether the beds in which gas occurs belong to the Simpson formation or to the underlying Siliceous lime. These beds contain water in wells drilled on the southwest and west flanks of the anticline, and the occurrence of the water indicates that the gas in these beds is restricted to the higher parts of the anticline. Well 1 , on plate 1 , in the southwest corner of the $\mathrm{NE}^{1} / 4 \mathrm{SW}_{1} 1 / 4$ sec. 9 , was drilled early in 1937 to test the Siliceous lime. It is reported that "granite" was encountered at shallow depth, and that no oil or gas was found in the Siliceous lime.

The log of well 5-288, in the SW1/4 sec. 9, reported gas in the Oswego lime and more gas in the Bartlesville sand. It is reported that other wells on the dome found gas in the Oswego lime. Well 8 , in the SW $1 / 4$ sec. 17 , produced 15 barrels of oil a day initially from the Squirrel sand at a depth of 1,235 feet; and two wells in the NE1/4 sec. 5 reported shows of oil from the Squirrel sand. The records of many other wells show no oil or gas in this bed, however. The Red Fork sand yielded from 10 to 25 barrels of oil a day initially in each of three wells and $11 / 2$ and 5 million cubic feet of gas a day in two wells in sec. 17; it yielded 15 barrels of oil a day from one well in the $\mathrm{SE} 1 / 4$ sec. 20, on the south and southwest flanks of the South Brown anticline. The Red Fork sand ranges from 15 to 40 feet in thickness and occurs at depths of 1,500 to 1,650 feet.

When the wells on the South Brown anticline that produce oil or gas from the Big lime have reached their economic limit of production they should be deepened to test the oil and gas possibilities of the Bartlesville sand and the Mississippi lime. Likewise, some of the wells now producing oil or gas from the Bartlesville sand might produce more oil if deepened into the upper part of the Mississippi lime. Additional gas wells could probably be obtained in the Big lime in the SW1/4 sec. 4 and the NW1/4. and $\mathrm{S} 1 / 2$ sec. 9 , and additional oil wells might be obtained in the $\mathrm{NW}_{1}^{1} / 4$ sec. 4 , the $\mathrm{E} 1 / 2$ sec. 5 , and the NE1/4 sec. 8. Several wells on these tracts which had shows of oil or gas in the Big lime probably would have been commercial producers if the wells had been treated with acid, inasmuch as the Big lime has responded to acid treatment with greatly increased 
yields in several places in Osage County. The absence of oil in the Big lime in the $\mathrm{E} 1 / 2$ sec. 4 , on the northeast flank of the anticline, is not readily accounted for, but its absence in the SE1/4 sec. 8 . and in secs. 16 and 17 is probably due to the fact that the upper limestone beds of the Big lime which produce oil in sec. 5 are absent. here, and their position is occupied by beds of shale. Gas in commercial amounts can likely be had from the Oswego lime on the crest of the anticline.

Additional oil from the Bartlesville sand can probably be obtained in the NW1/4 sec. 4 and the SE1/4 sec. 5, although the initial yields: would probably not exceed 40 barrels a day. The Bartlesville: sand is apparently absent in some wells in sec. 9 and in one well in sec. 8 and appears to be absent or very thin in sec. 16 . In sec. 17 the two wells producing from the Bartlesville sand have small yields, but it seems probable that additional Bartlesville sand 'wells with small daily yields could be obtained in the $\mathrm{N} 1 / 2$ sec. 21 and the $\mathrm{N} 1 / 2$ : sec. 20.

It appears probable that additional oil production could be obtained from the Mississippi lime in the $\mathrm{E} 1 / 2$ sec. 5 , the NW $1 / 4$ sec. 16 , and the E1/2 sec. 17 , and possibly in the N1/2 SW1/4 sec. 17 . Gas should be found on the higher parts of the South Brown anticline in the SW $1 / 4$ sec. 4 , and possibly in the NW1/1 sec. 9 in the upper part of the Mississippi lime. Ordovician rocks should be tested on the crest of the dome in the SW1/4 sec. 4 ; no well on this dome has been drilled below the Big lime.

South Fox dome (secs. 5 and 6).-The South Fox dome as mapped by $\operatorname{Ross}^{22}$ on the surface beds extends from the east-central part of sec. 31, T. 23 N., R. 11 E., southwestward across the central part of the W $1 / 2$ sec. 6, T. 22 N., R. 11 E. The subsurface structure contours (pl. 1) drawn on the top of the Oswego lime show the crest of the fold to be somewhat east of the crest on the surface beds. Twenty-two producing oil wells have been completed in secs. 5 and 6 , on the southeast flank of the fold, and one gas well in the NE1/4 sec. 6 , on the crest of the fold. Eighteen wells produced oil from the Bartlesville sand at depths of about 1,650 feet. Many of the wells have been abandoned. The Bartlesville sand ranges from 25 to 60 feet in thickness; it probably pinches out a short distance west of the oil-producing area, for the logs of two wells in the W1/2 sec. 6 and of well 15 , in the center of the north line of the $\mathrm{SW} 1 / 4 \mathrm{NE} 1 / 4$ sec. 6 , record no sand at the position of the Bartlesville sand. The initial yields of the wells ranged from 3 to 100 barrels of oil a day and averaged about 45 barrels. It is probable that the producing area in the Bartlesville sand could be expanded southward in the SE1/4 sec. 6 .

${ }^{22}$ Ross, C. S., op. cit.' (Bull. 686), pl. 30. 
Two wells in the NW1/4 sec. 5 produced oil and one well in the NE1/4 sec. 6 produced gas from beds in the upper part of the Mississippi lime. One of the wells in the NW1/4 sec. 5 had an initial production of 24 barrels of oil a day, and the yields of the other two wells were not learned. Additional oil and gas can probably be procured from the Mississippi lime by drilling additional wells or by deepening the Bartlesville sand wells when they have reached the economic limit of oil production from the Bartlesville sand and are ready for abandonment. Two wells in the NW1/4 sec. 5 produced 25 and 80 barrels of oil a day from the Big lime, at a depth of about 1,100 feet. The structural attitude of the beds on the South Fox dome appears not to be favorable for the accumulation of oil in Ordovician rocks.

Cedar Bluff dome.-The Cedar Bluff dome, in the west-central part of the township, has a structural relief of about 80 feet on the Oswego lime. From the crest of the dome the Oswego lime dips eastward more than 125 feet in less than three-quarters of a mile. The structural relief on the surface beds is about 40 feet. $^{23}$

Oil is produced on the Cedar Bluff dome from four beds and gas from two beds. Thirty-three oil or gas wells have been completed on the dome. Nineteen of these found oil or gas in the Burgess sandMississippi lime zone at a depth of about 1,700 feet; eleven wells yielded oil or gas from the Bartlesville sand at depths of about 1,600 feet; two wells produced oil or gas from the Red Fork sand; and one well found oil at a depth of a little less than 2,000 feet in beds that are in either the Simpson formation or the Siliceous lime. No $\log$ is available from which to identify the gas-bearing bed in an abandoned gas well, No. 2 on the map (pl. 1), in the SW1/4 NE1/4 sec. 18 , on the north nose of the anticline. The total depth of the well, which is reported to be 1,572 feet, indicates that the gas occurred in the Red Fork sand or the Bartlesville sand.

Oil wells producing from the Burgess sand or the upper part of the Mississippi lime had initial yields ranging from 5 to 60 barrels of oil a day, and two gas wells had initial yields from these beds of 4 and 11 million cubic feet a day. Additional oil from these beds could probably be found in the $\mathrm{S} 1 / 2$ sec. 18 and the NE1/4 sec. 19, but small yields should be expected.

The initial daily yields of wells that produced oil from the Bartlesville sand ranged from 5 to 125 barrels, and those of wells that produced gas ranged from $31 / 2$ to 32 million cubic feet. Inasmuch as the Bartlesville sand has yielded gas or oil in several localities on the Cedar Bluff dome, it is probable that additional oil and gas can be obtained from this bed in several places on the dome, but the small yields of the wells indicate that new wells also will have small

${ }^{23}$ Ross, C. S., op. cit. (Bull. 686), pl. 30. 
yields. One well in the northwest corner of the NE1/4 sec. 18 , however, had an initial yield of 32 million cubic feet of gas a day from the Bartlesville sand.

Well 2-197, in the SE1/4 sec. 7 , yielded initially 8 million cubic feet of gas a day, and well 1 , in the SW1/4 sec. 7, produced an undetermined amount of oil from sand believed to be the Red Fork sand. Shows of oil or gas or both were encountered in the Red Fork sand in many wells on the Cedar Bluff dome. It is probable that additional oil and gas can be expected from the Red Fork sand on parts of the dome, particularly in the $\mathrm{SE}^{1 / 4}$ sec. 7 and the $\mathrm{NE}^{1 / 4}$ sec. 18.

Secs. 22 and 23.-The small oil field in secs. 22 and 23 is in an area where the rocks deviate only slightly from the regional westerly dip. The occurrence of the oil which is found in the Bartlesville sand at depths of about 1,650 feet appears not to be controlled by the attitude of the beds. Well 9 , near the center of the SE1/4 sec. 22 , was drilled only recently, although the other wells have produced oil since 1929 or 1930 . The initial daily yields of the oil wells in the SE $1 / 4$ sec. 22 ranged from 10 to 40 barrels. The initial daily yields of the two abandoned producers in the SW1/4 sec. 23 were 10 and 20 barrels, and that of the abandoned producer in the NE1/4 NW $1 / 4$ sec. 26 was 80 barrels. Additional oil will probably be found in the Bartlesville sand west, south, and southwest of the field. Deepening of old wells may find additional oil lower in the sand. The well logs indicate that the bottoms of the producing wells are above the base of the sand body.

Sec. 36.-The three oil wells and one dry hole in the SW1/4 sec. 36 are near the north end of a low dome that lies on the northwest flank of a comparatively large anticline in the adjacent township on the south. The oil occurs in the upper beds of the Ordovician system at a depth of about 2,275 feet. It was not determined whether the oil-bearing beds are in the Simpson formation or the Siliceous lime. Additional oil could probably be found in the southeast corner of the SW1/4 sec. 36 . Only a relatively small daily yield should be expected, because the initial yields of the wells already drilled were less than 100 barrels a day.

Three abandoned oil wells near the east boundary of sec. 36 (shown on pl. 1 without colored overprint) had initial daily yields between 15 and 20 barrels of oil from the Taneha sand, which is in the lower part of the Cherokee shale. Two wells tested the uppermost beds in the Mississippi lime. The performance of the oil wells and the failures of the two tests of the Mississippi lime indicate that additional prospecting here is not warranted.

Lake View dome.-The Lake View dome trends northwestward through parts of secs. 34, 33, and 28 . The southern portion of the 
dome extends into the adjacent township on the south. A small subsidiary dome lies in sec. 28 on the northwest nose of the main dome. The crest of this subsidiary dome is 50 feet or more structurally lower than the crest of the main dome. The surface beds ${ }^{24}$ in secs. 33 and 34 are arched into a pronounced dome whose eastern flank is cut by two northwestward-trending faults that displace the beds about 50 feet vertically. 'The subsurface data were insufficient to determine whether the faults cut the Oswego lime and otherburied rocks. Consequently, no faults are shown on plate 1 . Oil is produced from the uppermost Ordovician rocks in secs. 33 and 28, on the Lake View dome. Several of the wells in sec. 28 were drilled recently, after the map was drawn. Accordingly, the mapping in the $\mathrm{S} 1 / 2$ sec. 28 should probably be modified somewhat on the basis of the data supplied by these recently drilled wells.

The oil occurs in thin beds of brown dolomite 10 to 22 feet below the top of the Siliceous lime, according to Floyd Miller, ${ }^{25}$ who examined samples of the oil-yielding beds. Shows of oil were found in sand in the overlying Simpson formation. The initial yields of most of the wells were less than 100 barrels a day. It is likely that additional wells will be drilled into these beds in the $\mathrm{S} 1 / 2$ sec. 28 , the $\mathrm{N} 1 / 2 \mathrm{~N} 1 / 2$ sec. 33, and the SW1/4.SW $1 / 4$ sec. 34. The $\log$ of well 1 , in the southwest corner of the NW1/4 SW1/4 sec. 34 recorded gas in sand that is presumably in the Simpson formation. The initial daily yield of gas is reported to have been 10 million cubic feet.

Gas occurs in the uppermost beds of the Bartlesville sand in sec. 33 on the Lake View dome. The initial yields of the wells ranged from less than 1 million to 5 million cubic feet a day. Additional gas could probably be obtained from the Bartlesville sand in the W1/2 sec. 34 and the $\mathrm{E} 1 / 2$ sec. 33 , on the dome.

Well 771 , in the NE1/4 SE1/4 sec. 33, found gas in the Oswego lime. The well flowed initially about 750,000 cubic feet of gas a day. The logs of the other wells in the vicinity do not record gas in the Oswego. lime. If additional wells are drilled the occurrence of gas should be noted, because gas is becoming increasingly important in this part of Osage County for use in repressuring partly depleted oil. sands.

Secs. 31 and 32.-An anticlinal nose in the SE1/4 sec. 31 is a northwestward-trending prong of the Edgewood dome, whose crest is in the NW1/4 sec. 5, T. 21 N., R. 11 E. Four wells in secs. 31 and 32, two of which are still producing, found oil at a depth of about 2,200 feet in beds that occur about 90 feet below the top of the Ordovician rocks. Whether the oil-bearing beds are in the Simpson formation

${ }^{24}$ Ross, C. S., op. cit. (Bull. 686), pl. 30.

${ }^{25}$ Oral communication. 
or in the Siliceous lime was not determined. It is reported that well 2 , in sec. 31 , had an initial yield of 1,800 barrels a day. The initial yields of the other wells were not learned. Four wells in secs. 5 and 6 of the township adjacent on the south had initial yields of gas from the Bartlesville sand that ranged from 8 to 16 million cubic feet a day. However, the logs of many of the wells in secs. 5 and 6, T. 21 N., R. 11 E., and of the wells in the SE1/4 sec. 31 and the SW $1 / 4$ sec. 32, T. 22 N., R. 11 E., record no gas in this sand. A detailed investigation of the original well records might show that most of the wells found gas; if so, additional gas wells could be drilled in the SE1/4 sec. 31 .

Anticline in northeastern part of township.-A large anticline in the northeastern part of the township is shown on plate 1. The crest of the anticline extends northwestward from sec. 18 of the: adjacent township on the east across secs. 12 and 1 into sec. 2 of this. township. A structural nose extends from the $\mathrm{W} 1 / 2$ sec. 12 southwestward across parts of secs. 11 and 14 into sec. 15 . Little confidence can be placed in the subsurface mapping in this part of the township, however, because there are so few control points on the subsurface datum bed-the Oswego lime. The positions of the contours were interpreted largely from the structure contour map of the surface beds prepared by Ross. ${ }^{28}$ The dry hole in the NE1/4 sec. 12 penetrated the uppermost beds of the Ordovician system to a depth of 100 feet, and the well in the northwest corner of the SW1/4 sec. 12 penetrated the uppermost 45 feet of these beds. The Ordovician rocks were recorded in the logs as sand, and most and possibly all of them are in the Simpson formation. It is impossible to determine from the logs whether the Siliceous lime was reached in eitherwell. The dry hole in the northwest corner of the SW1/4 sec. 12: had a 25-barrel show of oil from the Bartlesville sand at a depth. of 1,625 feet. Additional wells drilled in the area might discover. oil in commercial amounts in the Bartlesville sand. The locations: of prospective wells to explore the Bartlesville sand in the vicinity of the dry hole in the northwest corner of the SW $1 / 4$ sec. 12 need: not be guided by their structural positions on the anticline, because the data revealed by investigations of oil pools in the Bartlesville sand elsewhere in the region indicate that the oil occurrences in this sand are not controlled by the structural attitude of the beds. If, however, the Mississippi lime and the Simpson formation: and Siliceous lime are prospected, the location of the sites for wells. should be preceded by a detailed investigation of the structure of: the surface and subsurface beds.

${ }^{26}$ Ross, C. S., op. cit. (Bull. 686), pl. 30. 


\section{RECOMMENDATIONS}

The subsurface geologic investigation of T. 22 N., R. 11 E., indicates that additional oil may be found in secs. $4,5,8$, and 9 by deepening Big lime wells through the Bartlesville sand and the upper beds in the Mississippi lime. More gas can be obtained from the Big lime by drilling wells on the higher parts of the South Brown anticline in the SW1/4 sec. 4 and the W1/2 sec. 9, and additional oil can probably be obtained in this bed on the west flank of the anticline in the NW1/4 and $\mathrm{E}_{1} / 2$ sec. 5 and the $\mathrm{NE}_{1} 1 / 4$ sec. 8. The Bartlesville sand should be tested either by deepening old, wells or by drilling new wells in the $\mathrm{W}_{1} 1 / 2$ sec. 4 and the $\mathrm{E} 1 / 2$ sec. 5. Ordovician beds including the Simpson formation and the Siliceous lime should be tested for oil and gas on the crest of the dome in the SW1/4 sec. 4.

Additional oil may be found in the Bartlesville sand in the SE $1 / 4$ sec. $6, \mathrm{~S} 1 / 2$ sec. $17, \mathrm{~N} 1 / 2$ sec. $20, \mathrm{~N} 1 / 2$ sec. 21 , and $\mathrm{SE} 1 / 4$ sec. 22 , and gas in sec. 19 , the SE $1 / 4$ sec. 31 , and the SW $1 / 4$ sec. 34 .

The anticlinal nose in sec. 12 is worthy of a thorough geologic investigation of the surface and subsurface beds to determine the most favorable place to drill a test well. The well should be drilled at least 100 feet into the Siliceous lime. That a Bartlesville sand oil field may some day be developed here is suggested by a 25 -barrel oil show found in the Bartlesville sand in the dry hole in the northwest corner of the SW $1 / 4$ sec. 12 .

Additional oil and gas can probably be found in secs. 18 and 19 on the Cedar Bluff dome. More wells will likely be drilled on the dome in the $\mathrm{S} 1 / 2$ sec. 28 and the $\mathrm{N} 1 / 2 \mathrm{~N} 1 / 2$ sec. 33. The Ordovician rocks should be tested further on the Lake View dome by a well in the SW $1 / 4 \mathrm{SW} 1 / 4$ sec. 34 . The pronounced anticlinal nose that trends northeastward through the SE1/4 sec. 9 and the W1/2 sec. 10 is worthy of further investigation. This nose in the surface beds suggests that the subsurface beds form a dome-shaped fold whose crest may be in the NW1/4 sec. 10.

\section{T. 23 N., R. 11 E.}

About 600 wells, more than 500 of which have produced oil or gas, have been drilled in T. 23 N., R. 11 E. Some oil and gas was produced here as early as 1905 . Many of the wells in secs. 23, 24, and 25 were drilled in 1911 and 1912, and much of the drilling for oil and gas in secs. 29, 30, and 31 was done in 1912 and 1913 . The wells in sec. 1 were drilled mainly in 1913 and 1914; most of the wells in secs. 28, 32, and 33 were drilled between 1918 and 1920. The oil fields in secs. 16, 21, 8, and 17 were developed mainly in 1919 and 1922, and most of the wells in sec. 7 were drilled in 1918 and 1919. The oil fields in secs. $7,8,17$, and 18, the field in secs. 16 and 21 , the field in the 
W1/2 sec. 14 and sec. 15, and the field in the SW1/4 sec. 26 and sec. 35 were discovered and expanded subsequent to the mapping of the surface geology of the township by the Geological Survey ${ }^{27}$ in 1917 and 1918.

Most of the wells in this township yielded initially less than 50 barrels of oil a day; a very few exceeded 200 barrels of oil a day. However, as pointed out by Emery ${ }^{28}$ more than 15 years ago, the wells produce for a long time. Many of the wells have produced oil for more than 15 years and may continue producing for many years more.

The map of this township (pl. 1) was prepared mainly by Otto Leatherock, L. E. Kennedy, and W. R. Dillard in 1935 and 1936.

\section{OIL- AND GAS-PRODUCING BEDS}

Beds yielding oil or gas in commercial amounts in T. 23 N., R. 11 E., occur at eight stratigraphic positions. These beds, named in the order of their productiveness, are the Bartlesville sand, in the Cherokee shale; the Burgess sand-Mississippi lime zone, which occurs a short distance below the Bartlesville sand; the Cleveland sand, in the Coffeyville formation, 700 feet or more above the Bartlesville sand; the Big lime, which is a short distance below the Cleveland sand; the Siliceous lime, which lies about 500 feet below the Bartlesville sand; the Red Fork sand, in the Cherokee shale a short distance above the Bartlesville sand; the Squirrel sand, in the upper part of the Cherokee shale; and the Oswego lime, a short distance above the Squirrel sand. Each of these beds is described briefly below.

Bartlesville sand.-The Bartlesville sand has yielded oil or gas in 340 wells, widely distributed in the township. According to the well. logs each of the oil wells yielded initially from 5 to 200 barrels of oil a day, and each of the gas wells yielded from 1 to 18 million cubic feet of gas a day. About one-third of the wells have been abandoned. The Bartlesville sand occurs as lenses, from 10 to 150 feet thick, in the lower part of the Cherokee shale. Microscopic examination of cuttings from a few wells in this township indicates that the sand consists mainly of fine to medium subangular quartz grains. It is in general similar to the Bartlesville sand over a wide area in eastern Osage and adjacent counties and to the Bluejacket sandstone member of the Cherokee shale, which crops out in northeastern Oklahoma. The Bluejacket sandstone is believed to be equivalent to a part of the Bartlesville sand. Records of wells indicate that the Bartlesville-

\footnotetext{
${ }^{27}$ White, David, and others, Structure and oil and gas resources of the Osage Reservation, Oklahoma: U. S. Geol. Survey Bull. 686, pp. 1-10 and pl. 2, 1922.

${ }_{23}$ Emery, W. B., in White, David, and others, op. cit., p. 9.
} 
sand is present in most of the township at depths ranging from 1,400 to 1,700 feet but is absent locally in narrow areas between the thick lenses. It appears to be absent in a large area that embraces most of the $\mathrm{E} 1 / 2$ sec. 33 and secs. 34 to 36 .

The Bartlesville sand lenses, which occur in the several parts of the township, are not exact equivalents. For instance, the Bartlesville sand in the oil field that occupies parts of secs. 29 to 32 occurs at about the stratigraphic position of the uppermost part of the Bartlesville sand of the oil field that lies mainly in sec. 8. The sand in the sec. 8 area is from 30 to 150 feet thick, and the sand in secs. 29 to 32 is from 10 to 50 feet thick. A study of the well logs indicates. further that the sand in the eastern third of the township, where it is commonly from 25 to 150 feet thick, occurs approximately 50 feet lower in the Cherokee shale than the sand in the northwest quarter of the township. Cross sections made by matching well-log plats show that the sand body in the oil field in sec. 8 is a lens-shaped body with a convex top and a relatively flat base.

Burgess sand-Mississippi lime zone.-The Burgess sand is a lenticular bed of sand in the lowermost part of the Cherokee shale. In most places it is in contact below with the Mississippi lime, whose uppermost beds commonly consist of weathered chert and cherty limestone. These Mississippi lime beds are recorded as sand in many well logs. Consequently, the differentiation of the Burgess sand and the uppermost beds of the Mississippi lime could not be made from the drillers? logs. These beds can be differentiated by a microscopic examination of drill samples, but such an examination was made for this report for only one well (No. 7, in the SE1/4. sec. 28). Here the Burgess sand is 35 feet thick and yielded a show of oil; it consists mainly of coarse rounded and poorly sorted quartz sand lying on cherty limestone of Mississippian age. Seventy or more wells produce oil or gas from the Burgess sand-Mississippi lime zone. Most of these wells are in the southern part of the township. The initial daily yields of the oil wells ranged from 1 to 275 barrels and those of the gas wells ranged from 1 to 11 million cubic feet of gas.

Cleveland sand.-Many oil wells in secs. 28, 29, 32, and 33 obtain their oil from a lenticular bed of sand in the lower part of the Coffeyville formation, about 75 feet below the Checkerboard limestone member. A thin bed of limestone is recorded in some well logs immediately above the sand, and limestone is recorded in several other wells 10 to 30 feet above the sand. The sand is called the Cleveland sand because it occurs in the general stratigraphic position of the Cleveland sand of the Cleveland oil field, which lies in T. 21 N., R. 8. E., about 20 miles southwest of this township. The Cleveland sand in T. 23 N., R. 11 E., ranges from 10 to 100 feet in thickness; it occurs 
locally in two or more beds separated by shale. It is recorded as a single bed about 40 feet thick in the localities where it yields oil. A microscopic examination of a core of the sand from one well in the SW $1 / 4$ sec. 28 shows that there it is composed mainly of very fine angular quartz grains (0.062 to 0.125 millimeter in diameter) and contains 20 percent or more of silt.

The initial daily yields of the Cleveland sand wells ranged from 3 to 100 barrels of oil, but in most of the wells were between 20 and 40 barrels.

Big lime.-The Big lime (Oologah limestone) yields oil in 17 wells in secs. 32 and 33. The initial daily yields of the wells ranged from 10 to 460 barrels. The wells with the large initial yields are in the SW $1 / 4$ sec. 33. The Big lime is recorded in parts of this township as a single limestone bed 100 to 150 feet thick but in other parts as interbedded limestone and shale with a total thickness of only 50 feet. The oil-bearing portion, which is about 30 feet below the top of the formation, is recorded in the logs of wells in secs. 32 and 33 as sand and sandy lime from 10 to 40 feet thick.

The six wells in the SW1/4 sec. 33 that yielded oil from the Big lime were treated with acid during the later part of 1933 and the early part of 1934 . The average daily total yield from the six wells before acid treatment was about 5 barrels of oil, but after the treatment the yield increased to about 28 barrels. There was a gradual decline in yield after the acid treatment, and 2 years later the average daily total yield of the six wells was about seven barrels of oil. These data and other similar results from acid treatment of the Big lime in Osage County suggest that other wells that obtain showings or small yields of oil in the Big lime in this region can be made to yield profitable amounts of oil by treatment of the beds with acid.

Ordovician rocks.-Well cuttings of the pre-Pennsylvanian rocks in this township were not examined microscopically for this report, but on the basis of drillers' logs and mapping by Luther White ${ }^{29}$ it appears that his Simpson formation, of Ordovician age, is thin here. The Simpson formation occurs immediately below the Chattanooga shale in the eastern part of this township but is present directly below the Mississippi lime in the western part of the township, for the Chattanooga shale is absent there. ${ }^{30}$ The Siliceous lime consists of limestone and dolomite, some of which is cherty, and a small amount of sandstone. The total thickness of the Siliceous lime has a wide range. It is commonly thin on sharply folded domes and anticlines in Osage

\footnotetext{
${ }^{29}$ White, L. H., Subsurface distribution and correlation of the pre-Chattanooga ("Wil cox" sand) series of northeastern Oklahoma : Oklahoma Geol. Survey Bull. 40, vol. 1, pl. 2. 1926.

${ }^{30}$ Leatherock, Constance, and Bass, N. W., Chattanooga shale in Osage County, Okla. and adjacent areas: Am. Assoc. Petroleum Geologists Bull., vol. 20, no. 1, fig. 1, 1936.
} 
County but thickens abruptly away from the folds. It is 250 feet thick in the Amerada Petroleum Corporation's well 1, in the northwest corner of the SE $1 / 4$ sec. 7, where pre-Cambrian rocks, logged as "granite," were struck at a depth of 2,360 feet. It is at least 600 feet thick in Humphrey's well 4 , in the center of the east line of the SW $1 / 4$ sec. 16, which was drilled to a depth of 2,684 feet and was bottomed in limestone; it is at least 350 feet thick in the Barnsdall Oil Co.'s well 10, in the SE1/4 SW1/4 NW1/4 sec. 21, which was drilled to a depth of 2,445 feet without reaching the base of the limestone.

The uppermost beds in the Siliceous lime have yielded a small amount of oil in one well and gas in five or more wells. The initial daily yield of the oil well was 10 barrels, and that of the gas wells ranged from 3 to 40 million cubic feet. It is noteworthy that the Siliceous lime yields oil of high gravity $\left(40^{\circ} \pm\right)$ in many places in Osage County south of this township but has yielded only gas in northern Osage County, except in one well, which produced a small amount of oil of low gravity. The Siliceous lime yields oil in many places, however, in southeastern Kansas, a few miles north of Osage County. The gravity of the oil is between $25^{\circ}$ and $32^{\circ}$ A. P. I.

Red Fork sand.-The Red Fork sand, which is present locally in this township, yields a small amount of gas in two wells. It occurs between the Bartlesville sand below and the Pink lime above and is believed to be approximately equivalent to the Burbank sand of western Osage County.

Oswego lime and Squirrel sand.-The Oswego lime, which is the local name used for the Fort Scott limestone, has yielded a small amount of oil in one well in the southwestern part of the township and gas in three wells in sec. 7. The Squirrel sand, which occurs in the upper part of the Cherokee shale a short distance below the Oswego lime, yielded small amounts of oil in two wells in the southwestern part of the township. The wells were drilled into lower beds but were plugged back and produced oil from the Squirrel sand.

\section{STRUCTURE AND DEVELOPMENT}

In this township several domes, anticlinal noses, and synclines interrupt the regional westerly dip of the rocks. In fact, the local folds almost obscure the regional dip. The township forms part of a relatively broad belt of country in eastern Osage County that is characterized by pronounced structural relief, in contrast to a broad belt adjacent on the west that contains very few prominent folds. ${ }^{31}$ All the main structural features in the surface beds shown by the struc-

${ }^{a 1}$ Bass, N. W., Kennedy, L. E., Dillard, W. R., and Leatherock, Constance, Subsurface geology of Osage County, Okla. : United States Department of the Interior Press Memorandum 105368, p. 11, 1936 . 
ture contour map prepared by Emery,,$^{32}$ except the faults, are present and in general are somewhat more pronounced in the buried rocks. The available data are insufficient to determine whether the faults that displace the surface beds in secs. 4 and 9 also cut the Oswego lime and other deeply buried rocks.

Prominent folds in this township include the Brown anticline, in secs. 28 and 33 ; the Fox dome, in secs. 30 and 31 ; the Lombard dome, in secs. 16 and 21; the Hardy dome, in sec. 7; an unnamed anticline in sec. 8; the Labardie domes, in secs. 2, 3, and 4; an unnamed dome in secs. 11 to 14 ; two other unnamed domes that lie mainly in secs. 23 and 35 ; and an anticlinal nose in sec. 25 . The anticlinal nose in sec. 25 is a part of the Avant anticline, most of which lies in T. 23 N., R. 12 E. Several deep synclines and structural basins occupy the areas between the domes and anticlines.

In this township the structural attitude of the beds appears to have little bearing upon the occurrence of oil. Most of the oil here has been found in the Bartlesville sand, and studies throughout eastern Osage County indicate that the oil deposits in the Bartlesville sand are controlled by the pinching out of the porous sand beds and that they occur independently of the local attitude of the rocks. A sand lens commonly contains oil and gas throughout the greater part of its lateral extent, even though the beds are deformed into local anticlines and synclines.

The occurrence of oil and gas in the Bartlesville sand in this township appears to conform to the regional characteristics. Inspection of the subsurface structure-contour map (pl. 1) shows that the oilproducing areas in the Bartlesville sand throughout the eastern part of this township are distributed independently of the domes and synclines. In the western part of the township most of the oil field in sec. 8 falls on an anticlinal fold, but the oil-bearing sand crosses the syncline in the SW1/4 sec. 8 . Moreover, well 2 , in the $\mathrm{SE} 1 / 4 \mathrm{SW} 1 / 4 \mathrm{SW} 1 / 4$ sec. 8 , which is near the trough of the syncline, yielded initially 100 barrels of oil a day, but wells east and northeast of well 2 , in places where the rocks are higher structurally than they are at well 2 , had initial daily yields of only 10 to 50 barrels. Other examples are (1) the Bartlesville sand oil field that trends. northward along the east flank of the Fox dome in parts of secs. 31, 32,30 , and 29 and across the syncline in the SE1/4 sec. 19 and the SW1/4 sec. 20 ; and (2) the oil field in secs. 14 and 15, which extends from the crest of a local anticline southward down the flank into a syncline. Moreover, it is probable that if additional wells were drilled these fields would be expanded to include areas that are even

Emery, W. B., in White, David, and others, op. cit. (Bull. 686), pl. 2. 
lower and other areas that are structurally higher than those already yielding oil.

The occurrence of gas in the Bartlesville sand in sec. 7, structurally high on the Hardy dome, and in secs. 16 and 21, on the Lombard dome, and the occurrence of oil in the same sand on the west and southwest flanks of these domes suggest that the structural attitude of the beds has controlled the segregation and distribution of the gas and oil deposits locally within an oil- and gas-bearing sand body. However, gas has been found in the sand on the east flanks of each of these domes in structural positions considerably below that of much of the oil on the west flanks.

Brown anticline.-The crest of a sharp fold, called the Brown anticline by Emery, ${ }^{33}$ trends northeastward through secs. 33 and 28. It has a structural relief on the Oswego lime of more than 125 feet. Oil or gas occurs on the anticline in the Burgess sand or uppermost beds of the Mississippi lime, in the Bartlesville sand, in the Big lime, and in the Cleveland sand. Wells producing from the Cleveland sand or the Big lime should be deepened to test the Bartlesville sand and the uppermost beds of the Burgess sand-Mississippi lime zone before they are abandoned. The wide distribution of the wells producing oil or gas from beds in the Mississippi lime suggests that these beds will probably yield oil or gas locally elsewhere in secs. 28,32 , and 33. That the occurrence of oil and gas in these beds is not necessarily controlled primarily by the structural attitude of the rocks, is indicated by the positions of the wells on the Brown anticline.

Likewise records of many wells in this part of the township indicate that the occurrence of oil in the Cleveland sand is controlled by the lensing out of the oil-bearing beds rather than by the structural attitude of the rocks. The Cleveland sand in the SW1/4 sec. 28 is being investigated by one of the oil companies for the possibilities of water flooding. The Big lime yields oil in several wells in the SW1/4 sec. 33 and the $\mathrm{S} 1 / 2$ sec. 32 , low on the southwest flank of the Brown anticline and in the syncline that borders the anticline on the southwest. It is noteworthy that these localities are far removed from the higher parts of the Brown anticline; the relationship of the occurrence of the oil and the anticline is not apparent. Five wells in secs. 28 and 33 have been drilled into the uppermost beds of the Siliceous lime, but none reached pre-Cambrian rocks. Well 7, in the $\mathrm{SE} 1 / 4 \mathrm{sec}$. 28 , which is a short distance east of the crest of the anticline, found a show of oil with water in beds that occur about 60 feet below the top of the Siliceous lime. Also, well 12, in the SW1/4 sec. 33, low on the southward-plunging nose of the anticline, found a show of oil underlain by water at a depth of 2,135 feet, in beds that probably oceur in

as Emery, W. B., op. cit., pl. 2. 
the uppermost part of the Siliceous lime. The other deep wells are on the flanks of the Brown anticline and found water in the Siliceous lime. In the opinion of many operators these wells are sufficient to prove that the Siliceous lime is not oil-bearing on the Brown anticline. Because the oil pools in the Siliceous lime in this region are small in area, the possibility remains that a small oil-bearing area may be present in these beds on the crest of the fold.

Fox dome.-The Fox dome, in secs. 30 and 31, has a structural relief on the Oswego lime of at least 60 feet. Oil is produced from the Bartlesville sand along the east and northeast flanks of the dome and appears to occur independently of the attitude of the rocks. No. wells have been drilled on the highest part of the dome. This dome is prospectively valuable for oil and gas in the Burgess sand-Mississippi lime zone and in the Siliceous lime. A thin wedge of the Simpson formation, which is a possible oil-bearing bed, should be present here. Wells in secs. 30 and 31 that had small initial yields of oil from the Bartlesville sand and other wells that failed to produce in this sand indicate that the prospects for oil in the Bartlesville sand on the higher parts of the Fox dome are not favorable. However, local barren areas in Bartlesville sand oil pools are not uncommon. Therefore, if test wells are drilled on the Fox dome the possibility that oil or gas may occur in the Bartlesville sand should not be overlooked.

Lombard dome.-The area occupied by the Lombard dome was favorably recommended for drilling by Emery ${ }^{34}$ in 1922 . Since that date many oil wells and several gas wells drilled in secs. 16 and 21 have demonstrated that much of the area occupied by the dome is oiland gas-bearing. Most of the wells found oil in the Bartlesville sand. Eight wells on the dome were drilled into the uppermost beds of the Siliceous lime but all failed to find oil, although one well produced 14 million cubic feet of gas a day.

The anticlinal nose that trends northwestward across sec. 20 has not been thoroughly tested. Moreover, it appears probable that the nose contains a dome that is separated from the Lombard dome by a saddle near the east boundary of sec. 20. Inasmuch as the beds appear not to rise structurally so high on the nose as on the Lombard dome, the area is not particularly favorable for testing the oil possibilities of the Siliceous lime. Further investigation of the surface and subsurface beds is warranted, however. The two abandoned oil wells near the center of sec. 20 , which had initial yields of 10 and 20 barrels of oil a day, indicate that wells with small daily yields might be obtained in the Burgess sand-Mississippi lime zone.

st Emery, W. B., op. cit., p. 7. 
Anticline in sec. 8.-A narrow anticline trends northeastward through parts of secs. 17,8 , and 4 . It is in the midst of a broad area that is structurally low, and the crests of the small domes superposed on the anticline do not rise as high as the crests of the folds elsewhere in the township. Oil is produced here mainly from the Bartlesville sand. One well, now abandoned, produced oil from the Cleveland sand, and one well yielded gas from the Siliceous lime. The deepening of Bartlesville sand wells into the uppermost beds of the Mississippi lime might find additional oil. It is noteworthy that this field is one of the few Bartlesville sand oil fields in Osage County that appears to coincide with structural upfolds. The oil-producing Bartlesville sand in the syncline in the SW $1 / 4$ sec. 8 shows that even in this field the accumulation of oil is not confined to the higher parts of the fold. The oil-producing area might be expanded westward by the drilling of additional wells in the $\mathrm{N} 1 / 2$ sec. 8 , on the west side of the field.

Hardy dome.-The Hardy dome is a small sharp fold whose crest is in the $\mathrm{SE} 1 / 4$ sec. 7. The Oswego lime dips eastward from the crest of the dome more than 150 feet in three-quarters of a mile. Gas is produced from the Bartlesville sand on the higher part of the dome and low on the north and east flanks. The Bartlesville sand yields oil on the west and south flanks. Gas is produced from the Oswego lime in three wells on the higher part of the dome. Additional gas could probably be found in the Bartlesville sand and in the Oswego lime on the Hardy dome. All beds down to and including the Siliceous lime have been tested in several wells. Well 1 , in the northwest corner of the SE $1 / 4$ sec. 7, near the crest of the dome, is reported from an examination of well cuttings to have penetrated the Siliceous lime 225 feet, beneath which the drill passed through black weathered igneous or metamorphic rock and dolomite at depths of 2,332 to 2,347 feet. "Granite" that is generally believed to be of preCambrian age is recorded in the log at 2,358 to 2,384 feet.

Labardie domes.-The name "Labardie dome" was applied by Emery ${ }^{35}$ to a dome-shaped fold in the surface beds in secs. 3 and 4 ; a small dome in the NE1/4 sec. 3 and NW1/4 sec. 2 was not named by him. Both these domes are designated by the name "Labardie domes" on plate 1. The east dome covers a somewhat smaller area than the west dome, and the beds here are more steeply folded and lie at a higher altitude than those on the west dome. The Bartlesville sand yielded gas in four wells on the east dome, but logs on file do not show the amounts of the yields. The gas-producing area might be expanded by additional wells. The Burgess sand-Mississippi lime zone and the Siliceous lime have not been tested for oil

85 Emery, W. B., op. cit., p. 8 and pl. 2. 
and gas here but are worthy of a test near the center of the $\mathrm{E} 1 / 2 \mathrm{NE} 1 / 4$ sec. 3. If oil is found here in large amount, further consideration should be given to the west dome, in which all beds above the uppermost part of the Mississippi lime have been tested by three wells.

Other domes and anticlines.-A small dome, which should be given some consideration but should not be tested until additional geologic work is done in the area, is shown on plate 1 in the $\mathrm{N} 1 / 2$ sec. 1 . Altitudes of the datum bed in wells 1 and 2 in the SE $1 / 4$ sec. 1 and well 2 in the SW $1 / 4$ sec. 1 were not available. Therefore, the structure contours shown for this area on plate 1 are almost entirely hypothetical. The S1/2 sec. 34 also deserves additional study. The wide spacing of the structure contours here suggests that an anticlinal fold may be present. The structure-contour map of the surface rocks ${ }^{36}$ shows that the exposed beds here lie in a deep structural basin whose northsouth axis passes east of well 1 in the northwest corner of the SW $1 / 4$ sec. 34. It is possible that the writers' data relative to the altitude of the datum bed in well 1 are incorrect and that the axis of the subsurface syncline actually lies in the SW1/4 sec. 34, east of this well.

The higher parts of the broad-topped dome whose crest is near the northeast corner of sec. 14 remain untested for oil and gas in the Bartlesville sand, the Burgess sand-Mississippi lime zone, and the Siliceous lime. The Bartlesville sand oil-producing area in secs. 14 and 15 , on the southwest flank of the dome, could probably be expanded by the drilling of additional wells. The drilling of more wells in the $\mathrm{N} 1 / 2$ sec. 14 should result in extending the field in a northeasterly direction. Four of the five wells along the east line of the SE $1 / 4$ sec. 15 had initial yields of 50 barrels of oil a day, each, and the drillers' logs record the sand to be about 100 feet thick. Four of the wells have not been offset on the west. It appears reasonable to conclude that the oil-bearing sand body extends southwestward from the producing wells across much of the SE1/4 sec. 15 into the NE1/4 sec. 22.

Beds below the Bartlesville sand have not been tested on the crest of the small dome in the $\mathrm{SE} 1 / 4$ sec. 23 . The dry hole in the northeast corner of the SW1/4 sec. 23 found a show of oil in the Siliceous lime, according to the well log. The structure-contour mapping of the dome in sec. 23 (pl. 1) is controlled by data from 20 wells in the $\mathrm{W}^{1} 1 / 2$ and $\mathrm{SE} 1 / 4$ sec. $23, \mathrm{~N}^{1} 1 / 2$ sec. $26, \mathrm{NW}^{1} / 4$ sec. 25 , and $\mathrm{W}^{1} 1 / 2$ sec. 24. The logs of only two wells in the SE1/4 sec. 23 were used. Less confidence, therefore, can be placed in the structure contours shown on plate 1 in this area than elsewhere in the township. However, the structure-contour map of the exposed rocks by Emery ${ }^{36}$ shows an

${ }^{30}$ Emery, W. B., op. cit., pl. 2. 
anticlinal nose here. The structural map of the exposed beds, when considered with data on the attitude of the Oswego lime furnished by the logs of several wells, indicates that the subsurface beds have a dome-shaped attitude in the SE1/4 sec. 23. Wells on the south flank of the dome produce oil from beds that occur near the contact of the Cherokee shale and the Mississippi lime-beds that are referred to here as the Burgess sand-Mississippi lime zone. The oil-producing area in these beds could probably be expanded northward in secs. 23 and 24 , but the yields of the present producing wells indicate that small daily yields should be expected in the new wells. The distribution of the Bartlesville sand oil wells in sec. 24 indicates that additional wells should be drilled in the $\mathrm{N} 1 / 2$ of the section. Many of the wells in this section were drilled in 1911 and are still producing oil. It is noteworthy that all but three wells in the SE1/4 sec. 24 are still producing oil after a life of 25 years. A total of 306,609 barrels of oil was produced from the SW1/4 sec. 24 and 170,728 barrels from the SE1/4 sec. 24 between 1916 and 1934, inclusive, according to data compiled for this report by Otto Leatherock from records of the Osage Indian Agency. The amount of oil produced during the first 5 years of the life of half of the wells in the SW $1 / 4$ and all the wells in the $\mathrm{SE} 1 / 4$ is not included in these totals, because the data for these years were not available.

The anticlinal nose that trends westward through the E1/2 sec. 25 is the western prong of a large dome whose crest is in sec. 30 of the adjacent township on the east. One well in sec. 30, T. 23 N., R. 12 E., on the dome, found gas in the Siliceous lime, and other wells in the same section found gas in the Burgess sand-Mississippi lime zone. Wells in sec. 25, T. 23 N., R. 11 E., on the northwest flank of the dome, produced gas and oil from the Burgess sand or the uppermost beds of the Mississippi lime. All the gas wells and many of the oil wells have been abandoned.

\section{RECOMIMENDATIONS}

Detailed recommendations for new wells have already been made in the descriptions of the several parts of the township and will be only briefly summarized here. Test wells should be drilled into the Siliceous lime near the crest of the Fox dome, in secs. 30 and 31, on the Labardie dome in the NE1/4 sec. 3; on the dome whose crest is near the northeast corner of sec. 14; and on the dome in the SE $1 / 4$ sec. 23. Depths to the Siliceous lime in these places are about 2,000 to 2,150 feet. In view of the fact that the Siliceous lime has yielded gas in a few wells on domes in this township, it may contain only gas in these domes. However, the fact that several wells in the township have yielded shows of oil in the Siliceous lime indicates that oil may be found. 
Oil and gas should be found in the Bartlesville sand in many places in the township. Nearly all pools in the Bartlesville sand hold possibilities of expansion by the drilling of additional wells. Possibly the most favorable locality is in the Bartlesville sand field in secs. 14 and 15, which should be explored further in the SE1/4 and NE $1 / 4$ sec. 15 and the $\mathrm{N} 1 / 2$ sec. 14 . The distribution of the Bartlesville sand oil-producing, wells in the NW1/4 sec. 32 and the NE1/4 sec. .31 suggests that additional oil wells could be had in this sand in the $\mathrm{NE} 1 / 4$ sec. 31 . The information given on the $\log$ of well 36 , in the northwest corner of the SW1/4 NW1/4 sec. 33, indicates that the well produced initially 75 barrels of oil a day from the Bartlesville sand. It is recommended that offset wells be drilled east or south of this well to test the Bartlesville sand.

The wide distribution of the wells that have yielded oil from the Burgess sand-Mississippi lime zone suggests that many wells producing from younger beds should be deepened to these beds before abandonment. Most of the wells yielding oil from these beds have had small initial yields, but a few have yielded more than 200 barrels of oil a day.

Additional geologic study of the NE1/4 sec. 1 and the N1/2 sec. 20 might reveal structural features favorable to the occurrence of oil and gas.

The Bartlesville sand and Cleveland sand oil fields offer possibilities for repressuring and water flooding. The cost of flooding the Bartlesville sand is high because of the relatively great depth to the sand. Therefore, it may.be several years before water flooding of the Bartlesville sand will be profitable. 